\title{
The Noctuoidea (Lepidoptera) from Cuba described by Herrich-Schäffer and Gundlach in the Gundlach Collection, Havana
}

\section{Vitor O. Becker ${ }^{1}$}

\begin{abstract}
The taxonomic status of 94 nominal species of Noctuoidea from Cuba described by Herrich-Schäffer, and two species described by Gundlach is discussed. Type material of 49 nominal species preserved in Coll. Gundlach, Instituto de Ecologia y Sistemática, Havana, is evaluated. Seventy species names of Herrich-Schäffer and two of Gundlach are recognized, one genus name and 39 species names are synonymized, 16 new combinations, four reinstated synonyms and two species recalled from synonymy are established.

KEY WORDS. Noctuoidea, Cuba, Taxonomy, Herrich-Schäffer, Gundlach
\end{abstract}

HERRICH-SSCHÄFFER (1866-1870) described 93 species of Noctuoidea from Cuban material sent to him by Juan [Johannes Christopher] Gundlach (1810-1896). After study most of the material reverted to Gundlach in whose collection much of it is still preserved. However, 22 species were never returned to Cuba, perhaps because of Herrich-Schäffer's untimely death (1874), and at least some of them are now with part of Herrich-Schäffer's material in Coll. Staudinger (MNHU) (HAMPSON 1898).

During the course of two collecting trips to Cuba (September-October, 1989, and June-August, 1990), in collaboration with, and partial support of, the Instituto de Ecologia y Sistemática, Academia de Ciencias de Cuba, Havana, I had the opportunity to examine the moth material in the Coll. Gundlach, currently housed in that institution.

The material in Gundlach's collection is in a bad state of preservation, as is detailed below under each name. The collection was kept for many years in the Instituto de Segunda Enseñanza de la Habana (P. Alayo, pers. comm.). Under tropical conditions with high temperatures and humidity prevailing in Havana, the sad condition of the material is not surprising. Currently the collections are housed in a reasonably safe building with an air conditioning system that controls temperature and humidity.

The Coll. Gundlach is kept as a separate collection stored in modern glass-topped wooden drawers. Each specimen bears a label, about $20 \times 10 \mathrm{~mm}$, in Gundlach's handwriting with the full name of the genus and species and a printed number glued vertically along the left-hand margin (Fig. 27). This number is the one referred to in HERRICH-SSCHÄFFER (1866-1870) and in GUNDLACH (1881).

1) Departamento de Zoologia, Universidade de Brasília. Caixa Postal 04525, 70919-970 Brasília, Distrito Federal, Brasil. Research Associate. E-mail: vbecker@serrabonita.org 
A major problem regarding Herrich-Schäffer's Cuban species was that, except perhaps for a small number of specimens which had remained with HerrichSchäffer, the Gundlach material until recently had not been accessible for study by taxonomists outside Cuba. With none of the species originally illustrated, subsequent authors faced the near impossible task of having to interpret HerrichSchäffer's brief diagnoses. This study indicates that most authors, for example HAMPSON (1898-1913), reached the wrong conclusions resulting in many misidentifications and incorrect synonymies.

It is usually not clear from the original descriptions and from GUNDLACH (1881) how many specimens of each species were sent to Herrich-Schäffer and how many of those were later returned to Cuba. There is evidence that in a few cases Gundlach later added more specimens to the original series.

Although most of the specimens in Coll. Gundlach are part of the type-material, no lectotype selections are made in the present work. Lectotype designations should be deferred until that part of the material now in Coll. Staudinger (MNHU), and presumably in better condition, can also be considered. Regrettably it was not possible to obtain those specimens on loan.

Whilst working in Havana, material collected during the two mentioned trips was carefully compared with Gundlach's specimens. In those cases in which good matching was not possible, either because Gundlach's specimens were externally unrecognizable or because no matching specimen was collected, the abdomens were taken on loan. Back in Brazil, it was then possible to select specimens which approached the descriptions, to dissect them and compare their genitalia. The result was that, except for those species never returned to Gundlach, all the others were recognized. The taxa based on specimen not returned to Gundlach are arranged in the Nomenclatural Summary following PoOLE (1989).

Under each species reference is made to recognizable illustrations of the adults and/or genitalia; for the species not previously illustrated, pictures of adults and figures of the genitalia are given in this paper.

Abbreviations used in this work: (BMNH) The Natural History Museum, London; (IES) Instituto de Ecología y Sistemática, Havana; (MNHU) Museum für Naturkunde der Humboldt Universität, Berlin; (USNM) National Museum of Natural History, Washington; (VOB) ollection Becker, Brasília.

\section{NOMENCLATURAL SUMMARY}

Arctiidae

Arctiinae

Robinsonia Grote, 1865

dewitzi Gundlach, 1881

Ctenuchinae

Burtia Grote, 1866

cruenta (Herrich-Schäffer, 1866)

Correbidia Hampson, 1898

terminalis (Walker, 1856)

bicolor (Herrich-Schäffer, 1866), syn. $\mathbf{n}$.

Revta bras. Zool. 19 (2): 349 - 391, 2002 
cimicoides (Herrich-Schäffer, 1866)

subochrea (Herrich-Schäffer, 1866), syn. n.

fumata (Möschler, 1890), syn. n.

apicalis Schaus, 1904, syn. n.

germana (Rothschild, 1912), syn. $\mathbf{n}$.

steinbachi (Rothschild, 1912), syn. n.

Eunomia Hübner, 1818

insularis Grote, 1866

elegantula (Herrich-Schäffer, 1866)

nitidula (Herrich-Schäffer, 1866)

Horama Hübner, [1819]

difissa Grote, 1866

pretellus Herrich-Schäffer, 1866

pennipes (Grote, 1866)

plumosa Herrich-Schäffer, 1866

Lymire Walker, 1854

albipennis (Herrich-Schäffer, 1866)

Phoenicoprocta Druce, 1898

capistrata (Fabricius, 1775)

selecta (Herrich-Schäffer, [1854])

eximia (Herrich-Schäffer, 1866)

Syntomeida Harris, 1839

wrighti (Gundlach, 1881), comb. n., sp. rev.

parishi (Rothschild, 1911), syn. n.

Lithosiinae

Boenasa Walker, [1865]

Torycus Herrich-Schäffer, 1866, syn. n.

tricolor (Herrich-Schäffer, 1866), comb. $\mathbf{n}$.

toryca Schaus, 1924, syn. $\mathbf{n}$.

Paramulona Hampson, 1900

albulata (Herrich-Schäffer, 1866)

Pericopinae

Composia Hübner, [1820]

fidelissima Herrich-Schäffer, 1866

Sphaeromachia Grote, 1867

cubana (Herrich-Schäffer, 1866)

gaumeri (Druce, 1884), syn. n.

Noctuidae

Acontiinae

Cobubatha Walker, 1863

metaspilaris Walker, 1863

minima (Herrich-Schäffer, 1868), syn. n. 
Eublemma Hübner, [1821]

cinnamomeum (Herrich-Schäffer, 1868)

rectum (Guenée, 1852)

pallescens (Herrich-Schäffer, 1868)

Ponometia Herrich-Schäffer, 1868

exigua (Fabricius, 1793)

ochricosta Herrich-Schäffer, 1868

Spragueia Grote, 1875

apicalis (Herrich-Schäffer, 1868)

pantherula (Herrich-Schäffer, 1868)

uncinula (Herrich-Schäffer, 1868)

pestructana (Walker, 1865)

felina (Herrich-Schäffer, 1868)

trigridula (Herrich-Schäffer, 1868)

Thioptera Franclemont, 1950

Acronictinae

obliquata (Herrich-Schäffer, 1868)

Simyra Ochsenheimer, 1816

insularis (Herrich-Schäffer, 1868), comb. n.

henrici (Grote, 1873), syn. n.

evanida (Grote, 1873), syn. n.

fumosum (Morrison, 1874), syn. n.

Agaristinae

julithae (Benjamin, 1933), syn. $\mathbf{n}$.

Euscirrhopterus Grote, 1866

poeyi Grote, 1866

disparilis (Herrich-Schäffer, 1866)

Catocalinae

Antiblemma Hübner, 1823

inconspicuum (Herrich-Schäffer, 1870)

punctistriga (Herrich-Schäffer, 1870)

sterope (Stoll, 1780)

costaeluna (Herrich-Schäffer, 1870)

versicolor (Herrich-Schäffer, 1870)

Anticarsia Hübner, 1818

gemmatalis Hübner, 1818

elegantula (Herrich-Schäffer, 1869), syn. n.

Argidia Guenée, 1852

subvelata (Walker, 1865)

cubana Herrich-Schäffer, 1869, syn. n.

Baniana Walker, 1858

relapsa (Walker, 1858)

praeusta Herrich-Schäffer, 1868, nom. nud. 
bifida Herrich-Schäffer, 1869, nom. nud.

praecesta Gundlach, 1881, missp.

Caenurgia Walker, 1858

chloropha (Hübner, 1818)

chlorophis (Herrich-Schäffer, 1869), missp.

Coenipeta Hübner, 1818

medina Guenée, 1852

celadon Herrich-Schäffer, 1869, syn. n.

Dyomyx Guenée, 1852

inferior (Herrich-Schäffer, 1869)

Epidromia Guenée, 1852

lienaris (Hübner, 1823)

rotundata Herrich-Schäffer, 1869

Eulepidotis Hübner, 1823

modestula (Herrich-Schäffer, 1869)

Gonodontodes Hampson, 1913

dispar Hampson, 1913

dispar Herrich-Schäffer, 1868, nom. nud.

Hemeroplanis Hübner, 1818

apicigutta Herrich-Schäffer, 1869

Itomia Hübner, 1823

xylina Herrich-Schäffer, 1869

Melipotis Hübner, 1818

acontioides (Guenée, 1852)

penicillum (Herrich-Schäffer, 1868), sp. rev.

famelica (Guenée, 1852)

leucomelana (Herrich-Schäffer, 1868), syn. $\mathbf{n}$.

striolaris (Herrich-Schäffer, 1868), syn. n.

januaris (Guenée, 1852)

parcicolor (Herrich-Schäffer, 1868)

rectifascia (Herrich-Schäffer, 1868)

Orodesma Herrich-Schäffer, 1868

apicina Herrich-Schäffer, 1868

Parachabora Warren, 1889

triangulifera Hampson, 1901

purpurascens Herrich-Schäffer, 1868, nom. nud.

Phyprosopus Grote, 1872

tristriga (Möschler, 1890), comb. n.

tristriga Herrich-Schäffer, 1868, nom. nud.

albigutta Herrich-Schäffer, 1868, nom. nud.

fastigiatus Herrich-Schäffer, 1868, nom. nud.

intertribulus Dyar, 1921, syn. n.

albigutta Wolcott, 1924, syn. n. 
albiguttata Wolcott, 1924, missp.

fastigiatus (Schaus, 1940), syn. n.

Perasia Hübner, [1823]

helvina (Guenée, 1852)

helveola (Herrich-Schäffer, 1869)

Ptichodis Hübner, 1818

Condicinae

bistriga (Herrich-Schäffer, 1869)

Condica Walker, 1856

punctifera (Walker, [1857])

plumbago (Herrich-Schäffer, 1868), syn. n.

Euteliinae

Eutelia Hübner, [1823]

furcata (Walker, 1865)

blandula (Herrich-Schäffer, 1868), syn. n.

pertanda Dyar, 1925, syn. n.

piratica Schaus, 1940, syn. n.

caustiplaga Hampson, 1905, sp. rev.

Hadeninae

Callopistria Hübner, [1821]

floridensis (Guenée, 1852)

elegantulus (Herrich-Schäffer, 1868)

Catabenoides Poole, 2001

vitrinus (Walker, 1857)

divisus (Herrich-Schäffer, 1868), syn. rev.

Elaphria Hübner, 1818

agrotina (Guenée, 1852)

arnoides (Herrich-Schäffer, 1868), syn. rev.

nucicolora (Guenée, 1852)

contraria (Herrich-Schäffer, 1868), syn. n.

phalega (Schaus, 1940), syn. n.

guttula (Herrich-Schäffer, 1868), sp. rev.

Gonodes Druce, 1898

trapezoides (Herrich-Schäffer, 1868), sp. rev.

liquida (Möschler, 1886), syn. n.

violascens (Schaus, 1894), syn. $\mathbf{n}$.

leada (Druce, 1898), syn. n.

Lacinipolia McDunnough, 1937

parvula (Herrich-Schäffer, 1868)

Leucania Boisduval, 1828

inconspicua Herrich-Schäffer, 1868

hildrani (Schaus, 1938), syn. n.

ezrami (Schaus, 1938), syn. n. 
latiuscula Herrich-Schäffer, 1868

jaliscana Schaus, 1898, syn. n.

secta Herrich-Schäffer, 1868

clarescens (Hampson, 1905), misid.

hampsoni Schaus, 1940

Orthodes Guenée, 1852

majuscula Herrich-Schäffer, 1868

crenulata (Butler, 1890), syn. $\mathbf{n}$.

vesquesa (Dyar, 1913), syn. n.

Perigea Guenée, 1852

pectinata (Herrich-Schäffer, 1868), comb. n.

cuprescens (Hampson, 1909), syn. n.

Speocropia Hampson, 1908

trichroma (Herrich-Schäffer, 1868)

Spodoptera Guenée, 1852

pulchella (Herrich-Schäffer, 1868)

Tiracola Moore, 1881

grandirena (Herrich-Schäffer, 1868)

Herminiinae

Compsenia Dognin, 1914

gracillima (Herrich-Schäffer, 1870)

Heterogramma Guenée, 1854

terminalis (Herrich-Schäffer, 1870)

Lascoria Walker, 1859

nigrirena (Herrich-Schäffer, 1870)

Lophodita Möschler, 1890

tuberculata (Herrich-Schäffer, 1870)

Mastigophorus Poey, 1832

latipennis (Herrich-Schäffer, 1870)

Physula Guenée, 1854

acutalis Herrich-Schäffer, 1870

albirenalis Herrich-Schäffer, 1870

apicalis Herrich-Schäffer, 1870

herminialis Herrich-Schäffer, 1870

tristigalis Herrich-Schäffer, 1870

variegalis Herrich-Schäffer, 1870

Thursania Schaus, 1913

costigutta (Herrich-Schäffer, 1870)

Noctuinae

Agrotis Ochsenheimer, 1816

apicalis Herrich-Schäffer, 1868

repleta Walker, 1857

submuscosa Herrich-Schäffer, 1868, syn. n. 
Tandilia Köhler, 1954

rodea (Schaus, 1894)

divisa, Gundlach, 1881, part., misid.

Plusiinae

Ctenoplusia Dufay, 1970

calceolaris (Walker, [1858]), comb. n.

incrassata (Herrich-Schäffer, 1868), syn. n.

oxygramma (Geyer, 1832)

collateralis (Herrich-Schäffer, 1868)

Enigmogramma Lafontaine \& Poole, 1991

admonens (Walker, [1858])

binotula (Herrich-Schäffer, 1868), syn. n.

Notioplusia Lafontaine \& Poole, 1991

illustrata (Guenée, 1852)

egenella (Herrich-Schäffer, 1868)

Trichoplusia McDunnough, 1944

$n i$ (Hübner, [1803])

innata (Herrich-Schäffer, 1868)

Pyralidae

Chrysauginae

Lepidomys Guenée, 1852

irrenosa Guenée, 1852

reflexa (Herrich-Schäffer, 1869), syn. n.

\section{ALPHABETIC CATALOGUE}

The taxa treated below are listed in alphabetical order by species name. The numbers in "( )", refer to the numbers on the labels pinned to the specimens in Coll. Gundlach, and are the same numbers mentioned by Herrrich-Schäffer in the original descriptions and by GUNDLACH (1881) in his book on the Cuban Lepidoptera.

\section{albigutta Herrich-Schäffer}

"Nov. gen." albigutta Herrich-Schäffer, 1868: 181.

Material examined. None traced.

Remarks. This is the form of a highly variable species with a white orbicular on the forewings [see tristriga]. The name albigutta Herrich-Schäffer, 1868 is a nomen nudum; it was made available by WolcotT (1924: 177) [as Phiprosopus [missp.] albiguttata [missp.].

Identity. Phyprosopus albigutta (Wolcott, 1924), syn. n., a junior subjective synonym of Phyprosopus tristriga (Möschler, 1890) (Noctuidae, Catocalinae).

\section{albipennis Herrich-Schäffer}

Echeta albipennis Herrich-Schäffer, 1866: 117.

Material examined. One male, 1 female syntypes, "(69)". 
Remarks. In poor condition, externally unrecognizable; abdomen eaten internally by museum pests. According to HAMPSON (1898: 416) he examined the "type" in Coll. Staudinger (MNHU).

Identity. Lymire albipennis (Herrich-Schäffer, 1866) (Arctiidae, Ctenuchinae).

\section{albulata Herrich-Schäffer}

Mieza albulata Herrich-Schäffer, 1866: 120.

Material examined. One male syntype, "(399)".

Remarks. In poor condition; abdomen and wings (except veins of hind wings) destroyed by museum pests; not recognizable. According to HAMPSON (1900: 386) there is a male "type" in Coll. Staudinger (MNHU); the genitalia of this specimen were studied by FIELD (1951: 495).

Identity. Paramulona albulata (Herrich-Schäffer, 1866) (Arctiidae, Lithosiinae).

\section{apicalis Herrich-Schäffer (Figs 1, 28, 29)}

Agrotis apicalis Herrich-Schäffer, 1868: 149.

Material examined. One female type, "(556)".

Remarks. In poor condition but recognizable. Three specimens from Cuba (VOB 71598, 72838, 73420) match the specimen in Coll. Gundlach. Listed as an unrecognized species by HAMPSON (1903: 666), but recognized by FRANCLEMONT \& TODD (1983: 153). One male (VOB 71598) was dissected and its genitalia (Figs $28,29)$ are very similar to those of a male specimen of $A$. malefida Guenée, from Brazil (VOB 2645). Males of both species are easily distinguished by the hind wings: plain white in A. malefida, smoky gray along margins in A. apicalis (Fig. 1).

Identity. Agrotis apicalis Herrich-Schäffer, 1868 (Noctuidae, Noctuinae).

\section{apicalis Herrich-Schäffer}

Emmelia apicalis Herrich-Schäffer, 1868: 152.

Material examined. None traced.

Remarks. Not included in GundLACH (1881) and HAMPSON (1910a). Recognized by FRANCLEMONT \& TODD (1983: 134) as the species previously known as Heliocontia apicella (Grote, 1872). This species is being treated in a forthcoming work by WILTERDING (in press).

Identity. Spragueia apicalis (Herrich-Schäffer, 1868) (Noctuidae, Acontiinae).

\section{apicina Herrich-Schäffer}

Orodesma apicina Herrich-Schäffer, 1868: 179.

Material examined. One female type, "(765)".

Remarks. Badly damaged but recognizable: Undoubtedly the species studied by TODD (1964).

Identidy. Orodesma apicina Herrich-Schäffer, 1868 (Noctuidae, Catocalinae). 

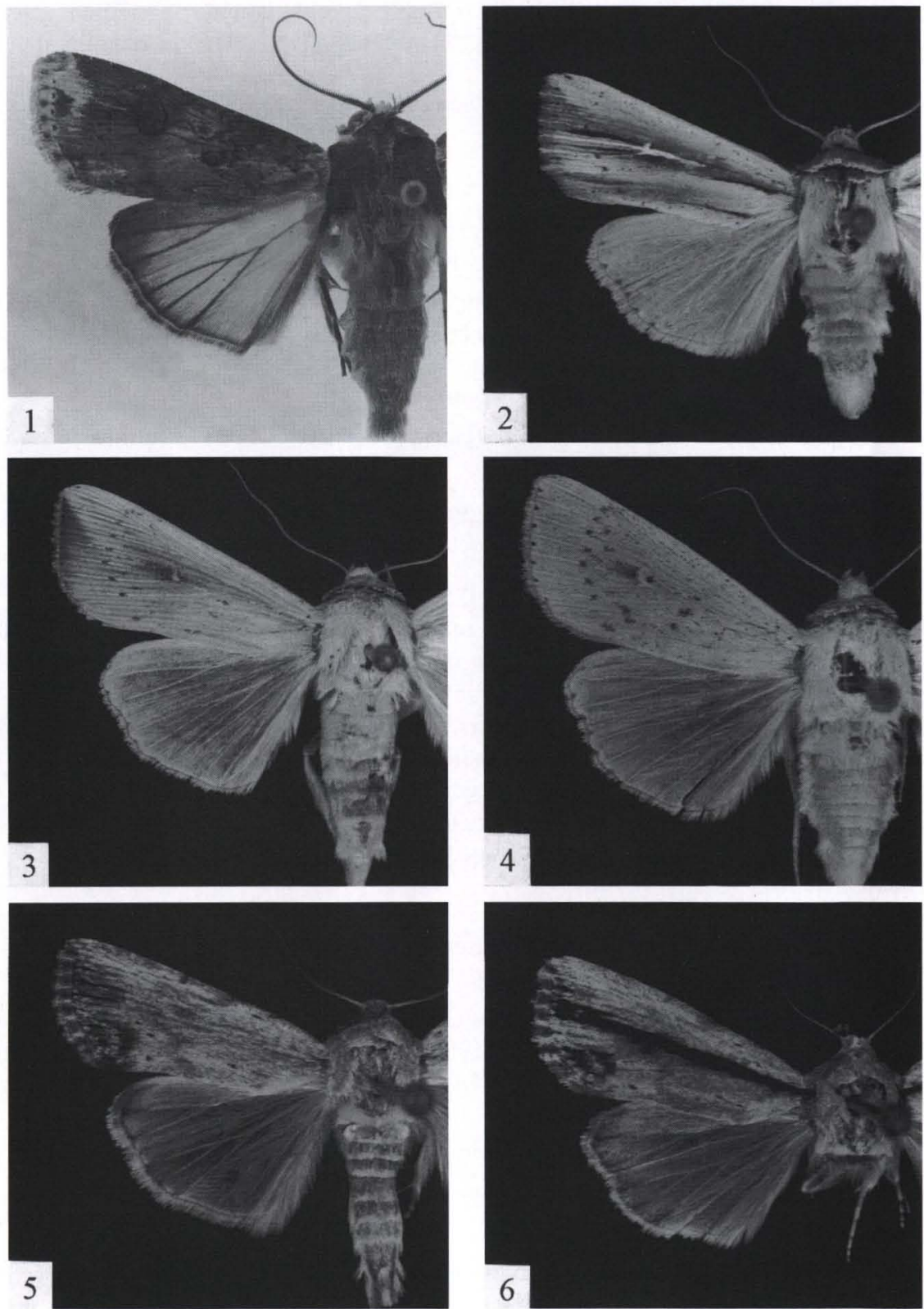

Figs 1-6. Adult Noctuidae moths from Cuba. (1) Agrotis apicalis (Noctuinae), male; (2) Leucania secta (Hadeninae), male; (3) L. latiuscula (Hadeninae), male; (4) L. inconspicua (Hadeninae), male; (5-6) Catabenoides vitrinus [= divisa] (Hadeninae): (5) male, (6) female. 

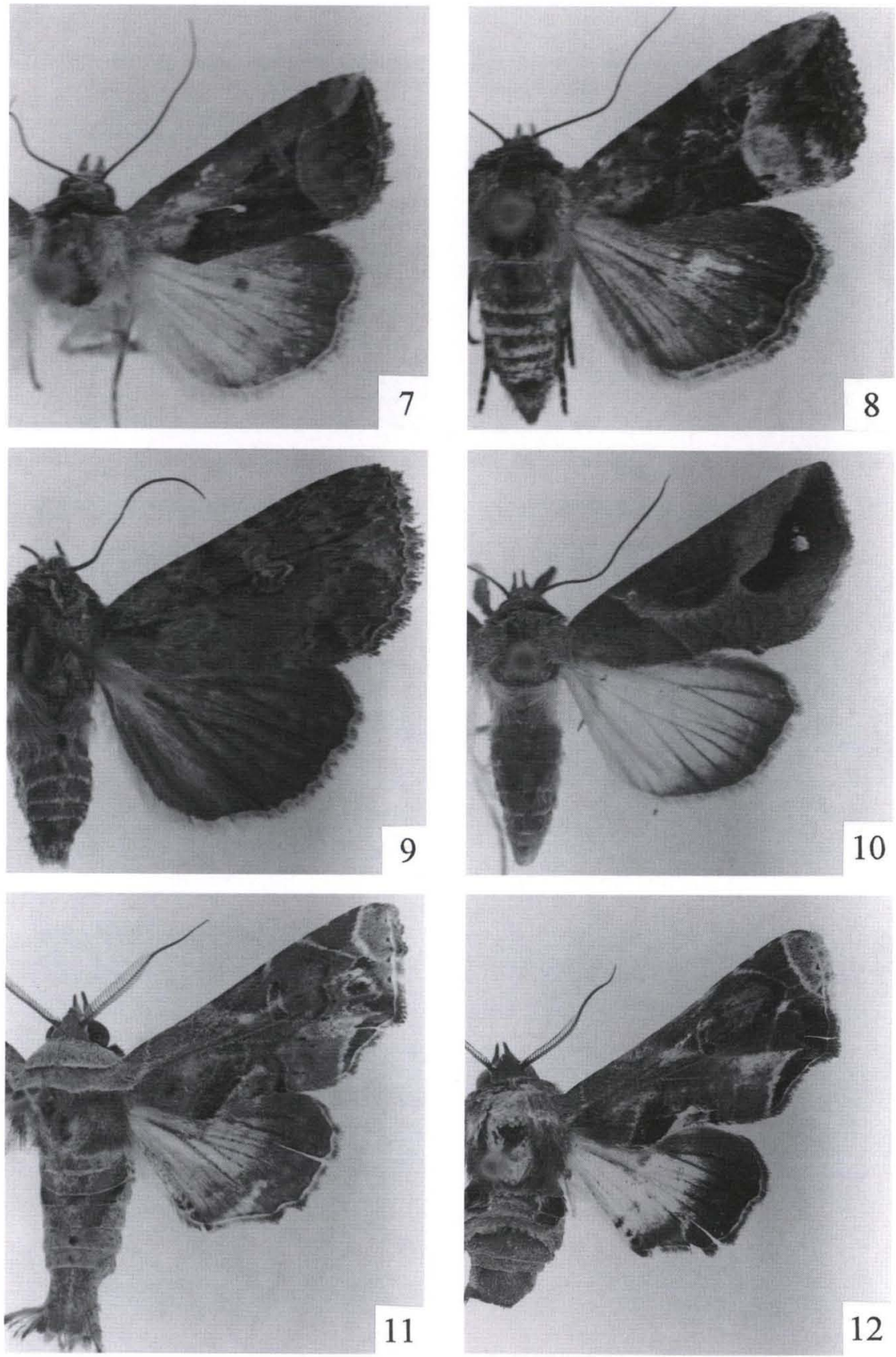

12

Figs 7-12. Adult Noctuidae moths from Cuba. (7-8) Elaphria guttula (Hadeninae): (7) male, (8) female; (9) Condica punctifera [= plumbago] (Condicinae), female; (10) Parachabora triangulifera [= purpurascens] (Catocalinae), female; (11) Eutelia furcata [= blandula] (Euteliinae), male; (12) E. caustiplaga (Euteliinae), female. 

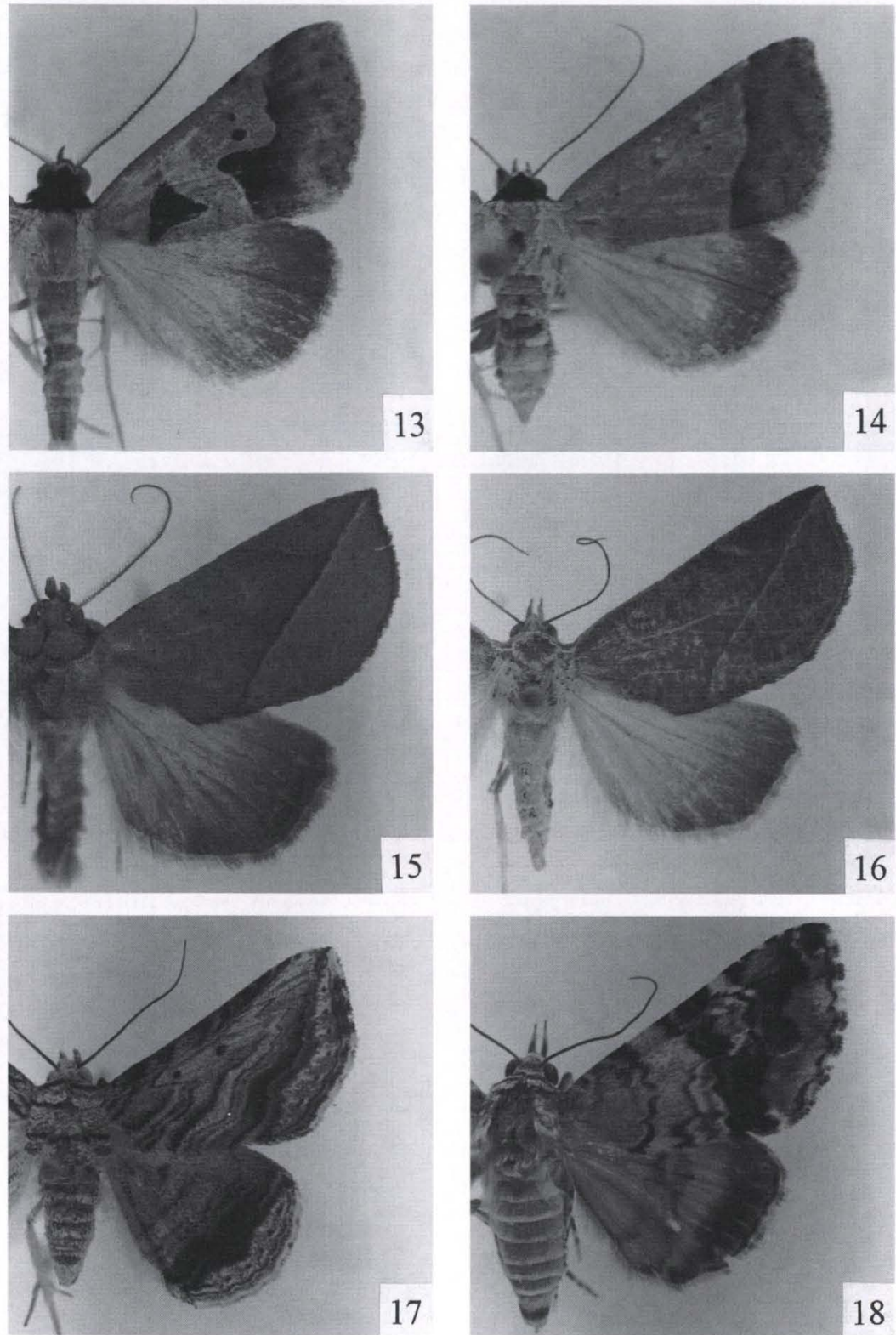

Figs 13-18. Adult Catocalinae (Noctuidae) moths from Cuba. (13-14) Baniana relapsa: (13) male [= praeusta], (14) female [= bifida]; (15-16) Phyprosopus tristriga: (15) male, (16) female; (17) Itomia xylina, male; (18) Coenipeta medina [= celadon], female. 

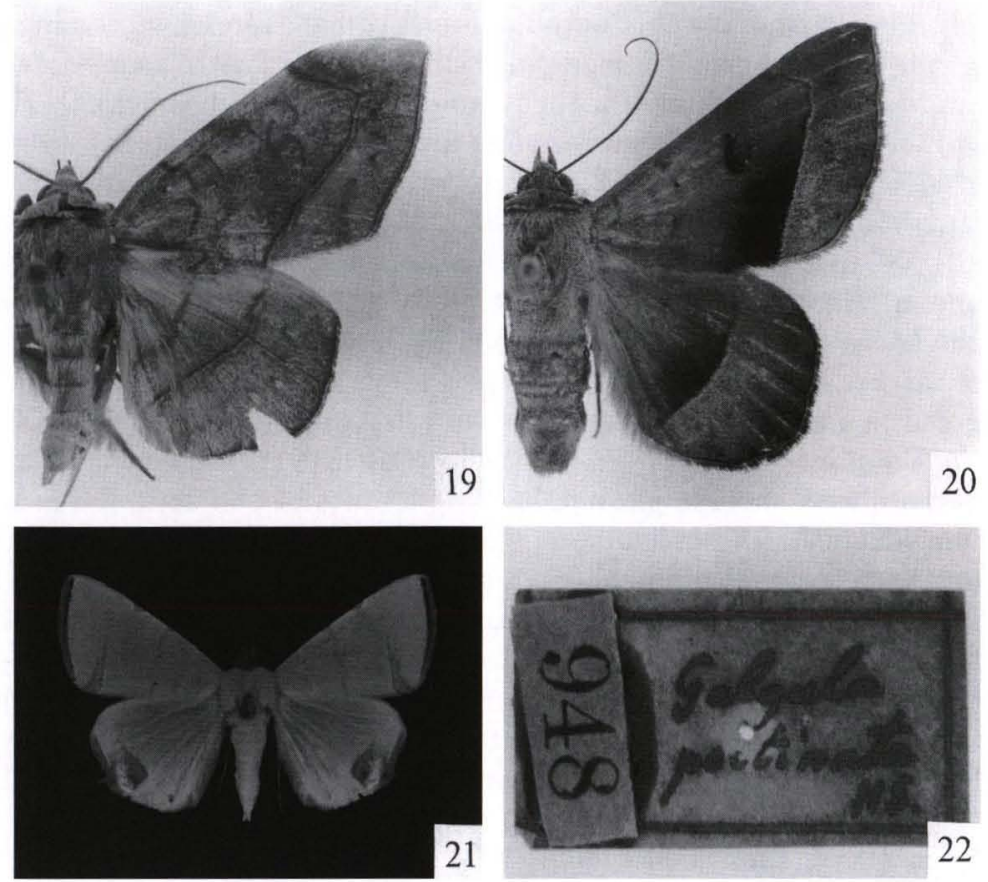

Figs 19-22. (19-21) Adult Catocalinae (Noctuidae) moths from Cuba. (19) Argidia subvelata [= cubana], male; (20) Epidromia lienaris [= rotundata], male; (21) Eulepidotis modestula, male; (22) Identification label in Gundlach's Collection.

\section{arnoides Herrich-Schäffer}

Celaeno arnoides Herrich-Schäffer, 1868: 154.

Material examined. One female type, "(865)".

Remarks. Badly faded but recognizable. Represented in VOB by a large series of specimens from Brazil, Mexico, British Virgin Islands and Cuba. Specimens from Cuba (VOB 71625, 72077, 72276) were compared with, and match, Gundlach's specimen. One male from the British Virgin Islands (VOB 66613) was compared with, and matches, the series of Elaphria agrotina (Guenée), in BMNH. C. arnoides was correctly synonymized with $E$. agrotina by HAMPSON $(1909: 478)$ but, incorrectly reinstated as a valid species by POOLE (1989: 350).

Identity. Elaphria arnoides (Herrich-Schäffer, 1868), syn. rev., a junior synonym of E. agrotina (Guenée, 1852) (Noctuidae, Hadeninae).

\section{bicolor Herrich-Schäffer}

Charidea bicolor Herrich-Schäffer, 1866: 116]

Material examined. One male type, "(645)".

Remarks. In poor condition; externally unrecognizable. 
This is an extremely polymorphic species with the forewings varying from plain orange through banded orange and black to almost black. As a result of such variation, this species, first described from the Antilles [Jamaica] as Pionia terminalis Walker, was also described four times from Cuban material: Correbia subochrea Herrich-Schäffer, 1866, syn. n., Charidea cimicoides HerrichSchäffer, 1866, C. bicolor Herrich-Schäffer, 1866, syn. n., Correbidia apicalis Schaus, 1904, syn. n., and from Puerto Rico as Lycomorpha fumata Möschler, 1890, syn. n. [HAMPSON (1900: 379) incorrectly synonymized $L$. fumata with the lithosiine Lycomorphodes strigosa (Butler, 1877); however, no Lycomorphodes species has yet been found in the Antilles]. The entire range of variation is represented in a series of 11 specimens collected together in one place: Cuba: Santiago, Turquino, 400m, 27-29.VII.1990 (VOB 73191). The male genitalia of the different forms, including examples from a series of 18 Puerto Rican specimens, are identical. The genitalia of males from Central America and Brazil, compared with, and matching, the types of C. germana (Rothschild, 1912), syn. n., and C. steinbachi (Rothschild, 1912), syn. n., are also identical. The descriptions of Herrich-Schäffer and Gundlach indicate that C. bicolor represents the yellow form of the species. Although I was unable to study the genitalia of Jamaican specimens, I examined a colour slide of the holotype of $C$. terminalis, and that of another specimen from Jamaica, kindly sent by Mr. M. Honey, BMNH, as well as a colour picture of an adult and a half-tone picture of its genitalia, kindly supplied by Dr. M. Barnes. They all match.

Identity. Correbidia bicolor (Herrich-Schäffer, 1866), syn. n., a junior subjective synonym of C. terminalis (Walker, 1856) (Arctiidae, Ctenuchinae).

\section{bifida Herrich-Schäffer (Fig. 14)}

"Genus nov." bifida Herrich-Schäffer, 1869: 154.

Material examined. None traced.

Remarks. This is a nomen nudum. Both the original description and the description in GuNDLACH (1881: 347) fit perfectly the female of Baniana relapsa (Walker) (Fig. 14), a sexually dimorphic species [see B. praeusta].

Identity. Correctly synonymized by SCHAus (1940: 250), with B. relapsa (Walker, 1858) (Noctuidae, Catocalinae).

\section{binotula Herrich-Schäffer}

Plusia binotula Herrich-Schäffer, 1868: 184.

Material examined. One male type, “(655)”.

Remarks. Faded, with hind wings partially destroyed by museum pests, but recognizable. A male from Cuba (VOB 71145) was compared with, and matches, Gundlach's specimen. Identical specimens from Brazil in VOB match the series of $P$. admonens Walker in BMNH. Incorrectly listed as a junior synonym of Pseudoplusia includens (Walker, [1858]) [=oo (Stoll, 1782), hom.)] by several authors including HAMPSON (1913: 522) and LAFONTAINE \& POOLE (1991: 49).

Identity. Enigmogramma binotula (Herrich-Schäffer, 1868), syn. n., a junior subjective synonym of E. admonens (Walker, [1858]) (Noctuidae, Plusiinae). 

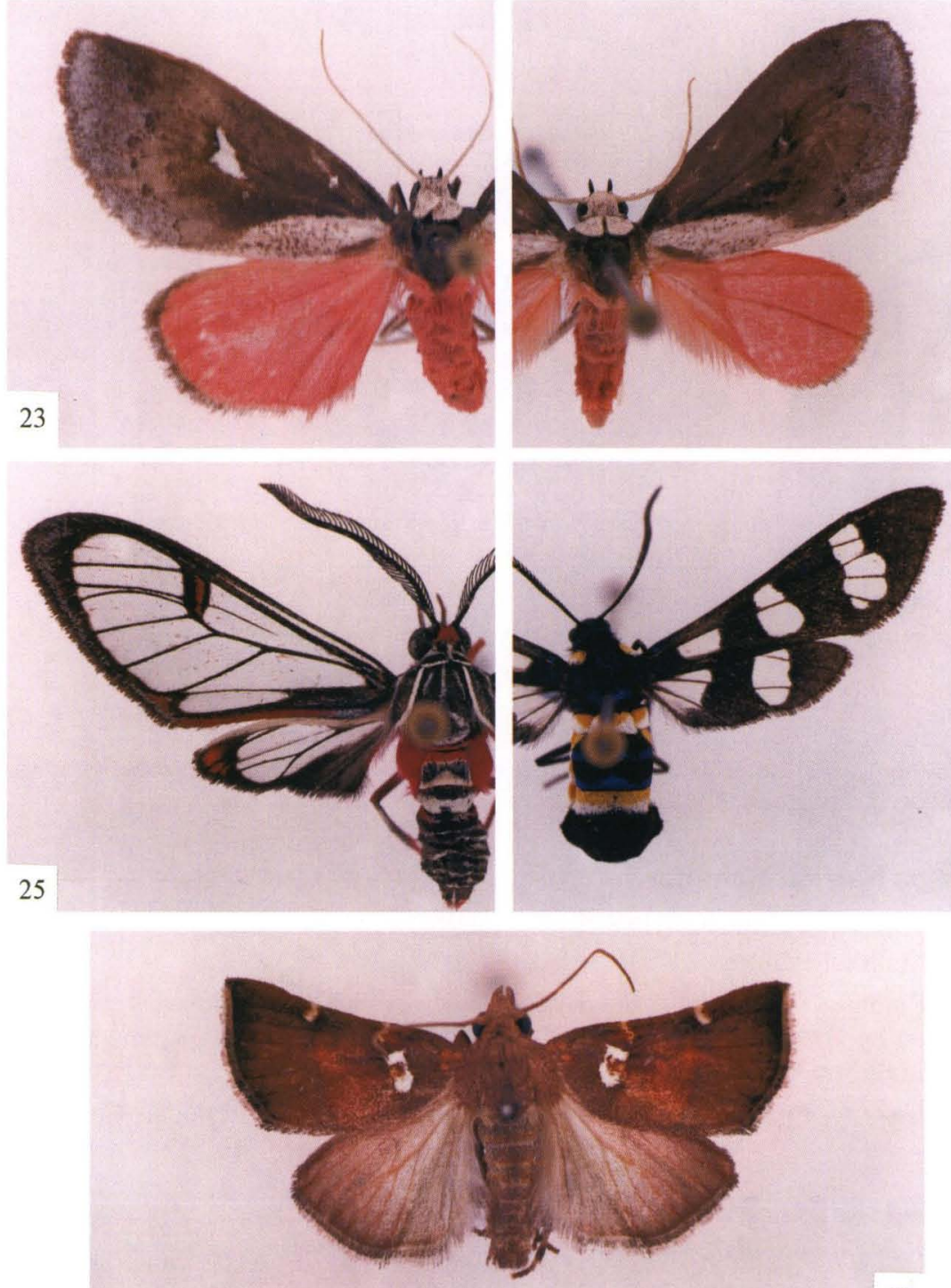

Figs 23-27. Adult Arctiidae and Pyralidae from Cuba. (23-24) Boenasa tricolor (Arctiidae, Lithosiinae): (23) female; (24) male; (25) Eunomia nitidula (Arctidae, Ctenuchinae), female; (26) Syntomeida wrighti (Arctiidae, Ctenuchinae), female; (27) Lepidomys irrenosa [= reflexa] (Pyralidae, Chrysauginae), male. 


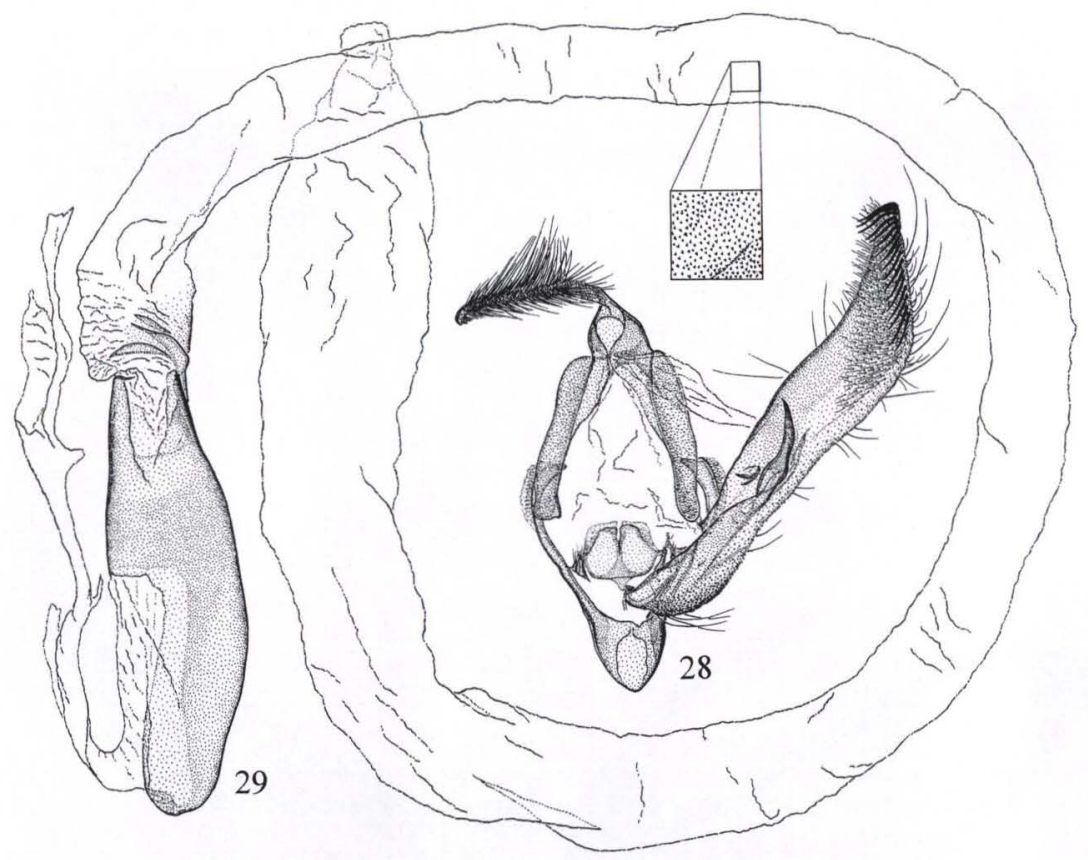

Figs 28-29. Agrotis apicalis (Noctuidae, Agrotinae), male genitalia. (28) ventral view, left valva and aedoeagus removed; (29) aedoeagus, lateral view [both same scale!].

\section{bistriga Herrich-Schäffer}

Phurys bistriga Herrich-Schäffer, 1869: 155.

Material examined. None traced.

Remarks. The original description indicates that the species was correctly identified by HAMPSON (1913: 109). In VOB there is a series of specimens from Cuba (VOB 70078, 70124, 71696, 72311, 73753). nae).

Identity. Ptichodis bistriga (Herrich-Schäffer, 1869) (Noctuidae, Catocali-

\section{blandula Herrich-Schäffer (Fig. 11)}

Eurhipia blandula Herrich-Schäffer, 1868: 180.

Material examined. One female type, "(64)".

Remarks. Faded and partially destroyed by museum pests, but recognizable. Three males and 4 females from Mexico, Puerto Rico and Cuba in VOB match the figure of Eutelia furcata (Walker) in DRUCE (1898: pl. 98, fig. 3) [as nattereri, misid.]. The Cuban specimens (VOB 73027) (Fig. 11) were compared with, and match, Gundlach's specimen; the Puerto Rican specimen matches the type of $E$. piratica Schaus, 1940, syn. n., and the Mexican specimen the type of E. pertanda Dyar, 1925 , syn. $\mathbf{n}$. The genitalia of both sexes from these specimens are conspe- 
cific. HAMPSON (1912: 24) incorrectly considered E. blandula and E. caustiplaga Hampson as synonyms. One specimen from Cuba (VOB 72851), (Fig. 12) representing a species different from E. blandula, was compared with, and matches, a syntype of $E$. caustiplaga Hampson, 1905a, sp. rev., in USNM.

Identity. Eutelia blandula (Herrich-Schäffer, 1868), syn. n., a junior subjective synonym of E. furcata (Walker, 1865) (Noctuidae, Euteliinae).

celadon Herrich-Schäffer (Fig. 18)

Coenipeta celadon Herrich-Schäffer, 1869: 154.

Material examined. One male type, "(36)".

Remarks. Faded, abdomen and hind wings partially destroyed by museum pests, but recognizable. In VOB there is a series of specimens from Brazil, Costa Rica and Cuba. The Cuban specimens (VOB 71168, 72303) (Fig. 23) match Gundlach's specimen, whereas one from Brazil (VOB 21081) was compared with, and matches, the holotype of $C$. medina Guenée in BMNH.

Identity. Coenipeta celadon Herrich-Schäffer, 1869, syn. n., junior subjective synonym of Coenipeta medina Guenée, 1852 (Noctuidae, Catocalinae).

\section{chlorophis Herrich-Schäffer}

Drasteria chlorophis Herrich-Schäffer, 1869: 155.

Material examined: None traced.

Remarks. Herrich-Schäffer mentioned "chlorophis $H Z$ '. "HZ" was an abbreviation of "Hübner Zuträge" used by Herrich-Schäffer, therefore this is a misspelling of Xestia chloropha Hübner, 1818, not a Herrich-Schäffer name as listed by POOLE (1989: 328). This species, currently included in Caenurgia Walker, 1858, is a common species throughout Southern United States and Northern Mexico, however, no specimen from the Antilles was either collected by the author or deposited in the USNM. GUNDLACH (1881: 350) repeated Herrich-Schäffer, listing this and Drasteria convalescens Guenée, 1852 [currently a junior subjective synonym of $C$. chloropha] mentioning, under $D$. convalescens "Esta espécie la recibí del amigo Poey. Ignoro donde fué cogida", and under $D$. chlorophis, "Para esta especie vale lo dicho en la especie precedente [D. convalescens]. Difiere poco." HAMPSON (1913: 68), listed "? Drasteria convalescens, Herr.-Schäff." under C. adusta Walker, 1865, a species described from Hispaniola and not yet collected in Cuba. Therefore the specimens studied by Herrich-Schäffer and Gundlach could be either Norht American, obtained by Poey from someone else, stray specimens, or misidentified $C$. adusta.

Identiy. Caenurgia chlorophis (Herrich-Schäffer, 1869), a misspelling of $C$. chloropha (Hübner, 1818) (Noctuidae, Catocalinae).

\section{cimicoides Herrich-Schäffer}

Charidea cimicoides Herrich-Schäffer, 1866: 116.

Material examined. One male, 1 female, syntypes, "(643)".

Remarks. Both in poor condition; the male unrecognizable; the female still with traces of the original dark fasciae. Correctly synonymized with Correbidia terminalis (Walker) by HAMPSON (1898: 519) [see C. bicolor]. 
Identity. Correbidia cimicoides (Herrich-Schäffer, 1866), a junior subjective synonym of C. terminalis (Walker, 1856) (Arctiidae, Ctenuchinae).

\section{cinnamomea Herrich-Schäffer}

Trothisa cinnamomea Herrich-Schäffer, 1868: 155.

Material examined. None traced.

Remarks. Widespread in the New World tropics, south to Argentina. The species currently known by this name, as recognized by HAMSPON (1910a: 171), fits the description given by GUNDLACH (1881: 319).

Identity. Eublemma cinnamomeum (Herrich-Schäffer, 1868) (Noctuidae, Acontiinae).

\section{collateralis Herrich-Schäffer}

Plusia collateralis Herrich-Schäffer, 1868: 184.

Material examined. None traced.

Remarks. Described by Herrich-Schäffer as similar to $P$. oxygramma (Geyer) and $P$. parallela Walker, [1858] (= P. oxygramma). HAMPSON (1913: 494), followed by subsequent authors (LAFONTAINE \& POOLE 1991: 47), correctly considered all three as a single species.

Identity. Ctenoplusia collateralis (Herrich-Schäffer, 1868), a junior subjective synonym of C. oxygramma (Geyer, 1832) (Noctuidae, Plusiinae).

\section{contraria Herrich-Schäffer (Figs 30, 31)}

Galgula contraria Herrich-Schäffer, 1868: 153.

Material examined. One male, 2 females, syntypes, "(934)".

Remarks. In poor condition; one of the females still shows traces of the original pattern; the male externally unrecognizable, however, its abdomen is preserved and has now been dissected (Figs 30, 31). In VOB there is a series from Brazil, Costa Rica, Puerto Rico, British Virgin Islands and Cuba. The Cuban specimens (VOB 71624) match Gundalch's specimens, whilst others were compared with, and match, the series of Elaphria nucicolora (Guenée) in BMNH and USNM. G. contraria was incorrectly synonymized with Micrathetis triplex (Walker, 1857) by HAMPSON (1909: 443). One specimen from Puerto Rico (VOB 67747) that matches the type of E. phalega (Schaus, 1940), syn. n. was also dissected. All specimens of this species have identical genitalia.

Identity. Elaphria contraria (Herrich-Schäffer, 1868), syn. n., a junior synonym of E. nucicolora (Guenée, 1852) (Noctuidae, Hadeninae).

\section{cruenta Herrich-Schäffer}

Gundlachia cruenta Herrich-Schäffer, 1866: 108.

Material examined. None traced.

Remarks. According to HAMPSON (1898: 361-362) one male "type"and one female "type" in Coll. Staudinger (MNHU) represent two different species. He restricted the identity of $G$. cruenta to the male, and stated that the female was Burtia rubella Grote, 1866.

Identity. Burtia cruenta (Herrich-Schäffer, 1866) (Arctiidae, Ctenuchinae). 

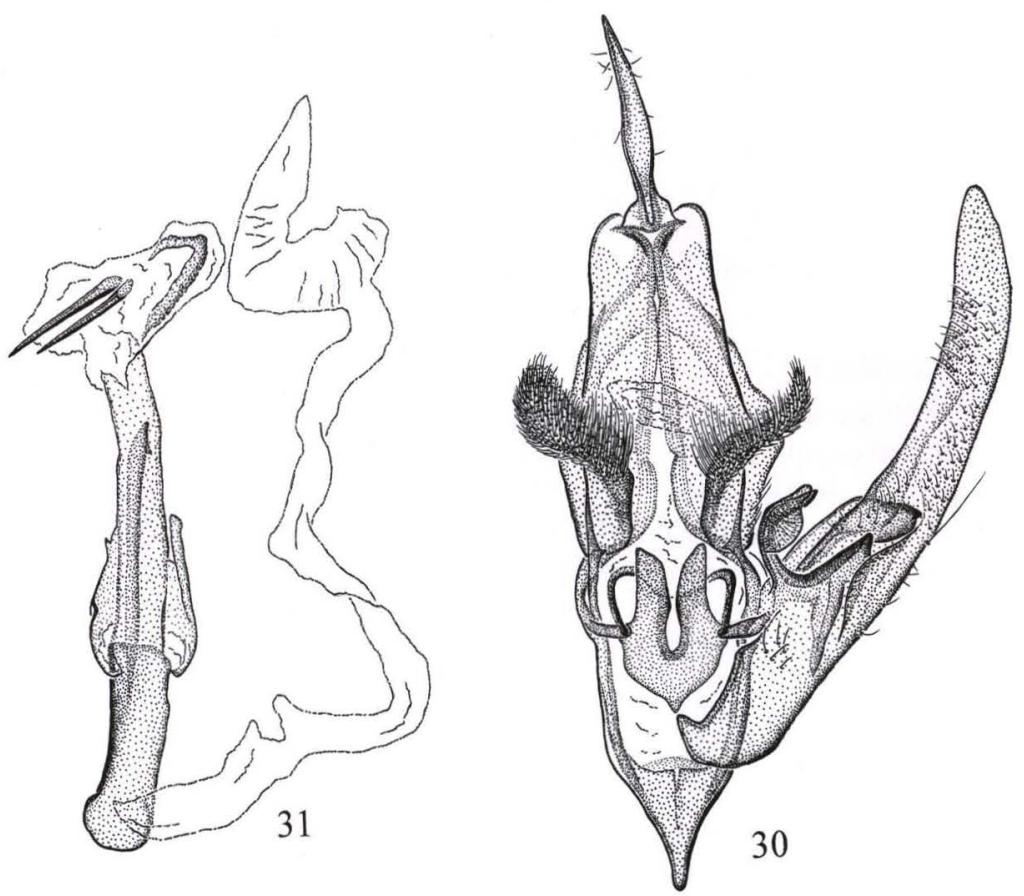

Figs 30-31. Elaphria nucicolora ["Type" of E. contraria] (Hadeninae), male genitalia. (30) ventral view, left valva and aedoeagus removed; (31) aedoeagus, dorsal view.

\section{cubana Herrich-Schäffer (Fig. 19)}

Argidia cubana Herrich-Schäffer, 1869: 158.

Material examined. One male, 2 females, syntypes, "(350)”.

Remarks. Faded; the male abdomen destroyed by museum pests, but all are recognizable. GUNDLACH (1881: 370) stated that the male had not been seen by Herrich-Schäffer; it is therefore not part of the type-series. In VOB there is a series from Costa Rica, Mexico, Puerto Rico and Cuba. The Cuban specimens (VOB 70404, 71167) (Fig.19), were compared with, and match, Gundlach's specimens and the type of A. aufidia Schaus, 1912, a synonym of A. subvelata (Walker) (POOLE 1989: 119). Herrich-Schäffer correctly described $A$. cubana as very similar to $A$. wedelina (Stoll, 1782). They are almost identical, but the male hind wing tornus of A. wedelina has a strong indentation resembling the beak damage of a bird.

Identity. Argidia cubana Herrich-Schäffer, 1869 (Noctuidae, Catocalinae), syn. n., a junior synonym of A. subvelata (Walker, 1865).

\section{cubana Herrich-Schäffer}

Pericopis cubana Herrich-Schäffer, 1866: 131.

Material examined. One male, 1 female, syntypes, "(640/597)". 
Remarks. Badly damaged but still recognizable. In VOB there is a series of specimens from Mexico and Cuba. The Cuban specimens (VOB 70448, 71061) were compared with, and match, Gundlach's specimens, whereas the Mexican specimens were compared with, and match, the original description and figure of Phaloë gaumeri Druce (1884: 107, pl. 11, figs 4, 5), syn. n. DRUCE (1897: 385) had already suspected that $P$. cubana and $P$. gaumeri might be the same.

Identity. Sphaeromachia cubana (Herrich-Schäffer, 1866) (Arctiidae, Pericopinae).

\section{dewitzi Gundlach}

Robinsonia dewitzi Gundlach, 1881: 265.

Material examined. One male type [no number label].

Remarks. In very bad condition; however, some forewing pattern still preserved allows recognition. A male from Cuba (VOB 70443) was compared with, and matches, Gundlach's specimen. It is the species recognized by HAMPSON (1920: $5)$.

Identity. Robinsonia dewitzi Gundalch, 1881 (Arctiidae, Arctiinae).

\section{dispar Herrich-Schäffer}

"Nov. gen." dispar Herrich-Schäffer, 1868: 181.

Material examined. One male, 1 female, syntypes "(439)".

Remarks. The male faded and with hind wings partially destroyed by museum pests but recognizable; the female in very bad condition, abdomen and right hind wing missing, and the rest partially destroyed by museum pests. A series from Cuba (VOB 70084, 70393, 71153, 72106, 72296) was compared with, and matches, Gundlach's specimens. The name dispar Herrich-Schäffer is a nomen nudum, but was made nomenclaturally available by HAMPSON (1913: 147).

Identity. Gonodontodes dispar Hampson, 1913 (Noctuidae, Catocalinae).

\section{disparilis Herrich-Schäffer}

Heterandra disparilis Herrich-Schäffer, 1866: 134.

Material examined. None traced.

Remarks. It is very likely that no author has seen any of the original specimen(s) after GUNDLACH (1881: 234); however, the descriptions of HerrichSchäffer and Gundlach leave no doubt about the identity of this species. TODD (1966: 4-9) reviewed the genus and presented illustrations of the species. This species was described twice in the same year; TODD (1966) established the priority of E. poey Grote.

Identity. Euscirrhopterus disparilis (Herrich-Schäffer, 1866), a junior subjective synonym of E. poey Grote, 1866 (Noctuidae, Agaristinae).

\section{divisa Herrich-Schäffer (Figs 5, 6)}

Callierges divisa Herrich-Schäffer, 1868: 147.

Material examined. One female type, "(739)".

Remarks. In poor condition, wings faded and partially destroyed by museum pests, but still recognizable. In VOB there is a male and 2 females (Figs 5, 6) from Cuba (VOB 73023). The females were compared with, and match, Gundlach's 
specimen, and the male, including its genitalia, the series identified as Catabenoides vitrinus (Walker) by Dr. R.W. Poole (USNM). HAMPSON (1909: 236) had correctly synonymized both, but FRANCLEMONT \& TODD (1983: 146) reinstated C. divisa as a valid species. There are several species congeneric with $C$. divisa in the Antilles, some of them undescribed, however only $C$. vitrinus has the female with a well defined fascia along the middle of fore wings (Fig. 6), as also described by GundLACH (1881: 298) for C. divisa. Another male, "(825)" from Puerto Rico, in Coll. Gundlach, is very likely the one mentioned by him (1881:298) as "Un ejemplar de Puerto Rico, que creo de igual especie, difiere por tener el cuello negruzco, y la raya longitudinal está dividida por una nervura del color del fondo y tiene además un punto negro dentro de un fondo blanco... Será una variedad?" This is not $C$. divisa but a good specimen of Tandilia rodea (Schaus, 1894). It is interesting to note that no other specimen of $T$. rodea from the Antilles has been found in any of the collections studied by the author (BMNH, IES, USNM and VOB).

Identity. Catabenoides divisus (Herrich-Schäffer, 1868), syn. rev., a junior subjective synonym of $C$. vitrinus (Walker, 1857) (Noctuidae, Hadeninae).

\section{egenella Herrich-Schäffer}

Plusia egenella Herrich-Schäffer, 1868: 183.

Material examined. One female type, "(471)".

Remarks. In a very bad condition. Almost totally destroyed by museum pests and with head missing, but still recognizable. Synonymized with $P$. abeona Druce, 1889 by HAMPSON (1913: 436), and with $P$. illustrata (Guenée) by LAFONTAINE \& POOLE (1991: 56).

Identity. Notioplusia egenella (Herrich-Schäffer, 1868), a junior subjective synonym of $N$. illustrata (Guenée, 1852) (Noctuidae, Plusiinae).

\section{elegantula Herrich-Schäffer}

Glaucopis elegantula Herrich-Schäffer, 1866: 114.

Material examined. None traced.

Remarks. HAMPSON (1898: 203) synonymized G. elegantula with E. insularis Grote, and stated that there is a "type" in Coll. Staudinger (MNHU). Both names were proposed in the same year; TODD (1966) established the priority of Grote's work.

Identity. Eunomia elegantula (Herrich-Schäffer, 1866), a junior subjective synonym of $E$, insularis Grote, 1866 (Arctiidae, Ctenuchinae).

\section{elegantula Herrich-Schäffer}

Thermesia elegantula Herrich-Schäffer, 1869: 159.

Material examined. None traced.

Remarks. This is only a form of Anticarsia gemmatalis Hübner, as GUNDLACH (1881: 373) suspected: "El Dr. Herrich-Schäffer separó como una especie un ajemplar de mi colección, aunque podría ser la misma gemmatalis; pero faltan transiciones y así la admito como diferente. Ella es pardo-rojiza con las líneas en zig-zag apenas indicadas, con la línea oscura oblícua algo más encorvada y con su 
borde interno amarillento. Una diferencia notable consiste en que la mancha reniforme es blanca, lo que no es en gemmatalis.". In VOB there are specimens from Brazil (VOB 6435, 6455) with the oblique line marked with yellow internally and bearing a white reniform as described by Gundlach. This species is the "velvetbean catterpillar moth", a pest of soybean in the New World.

Identity. Anticarsia elegantula (Herrich-Schäffer, 1869), syn. n., a junior subjective synonym of $A$. gemmatalis Hübner, 1818 (Noctuidae, Catocalinae).

elegantulus Herrich-Schäffer

Eriopus elegantulus Herrich-Schäffer, 1868: 117.

Material examined. One female type, "(38)".

Remarks. Faded and partially destroyed by museum pests, but still recognizable. The synonymy established by HAMPSON (1908: 548) is correct.

Identity. Callopistria elegantula (Herrich-Schäffer, 1868), a junior subjective synonym of $C$. floridensis (Guenée, 1852) (Noctuidae, Hadeninae).

\section{eximia Herrich-Schäffer}

Glaucopis eximia Herrich-Schäffer, 1866: 115.

Material examined. None traced.

Remarks. According to HAMPSON (1898: 199) there is a "type" in Coll. Staudinger (MNHU).

Identity. Phoenicoprocta eximia (Herrich-Schäffer, 1866) (Arctiidae, Ctenuchinae).

\section{fastigiata Herrich-Schäffer (Fig. 15)}

"Nov. gen." fastigiata Herrich-Schäffer, 1868: 181.

Material examined. One male, 1 female, syntypes, "(568)".

Remarks. The male is faded, partially destroyed by museum pests; the female is badly damaged, with head missing, and partially destroyed by museum pests. The male is almost identical to the specimen labeled "tristriga" in Coll. Gundlach whereas the female represents a form with dark fuscous postmedian fascia of the same highly variable species. A specimen from Cuba (VOB 71178) (Fig. 15) matches this form and the type of Phyprosopus intertribulus Dyar, 1921, syn. rev. $P$. intertribulus was synonymized with $P$. fastigiata by SCHAUS (1940: 260); this was overlooked by POOLE (1989: 802) who considered it as a valid species. The name fastigiata Herrich-Schäffer is a nomen nudum; it was made available by SCHAUS (1940: 260) [see tristriga].

Identity. Phyprosopus fastigiatus (Schaus, 1940), syn. rev., a junior synonym of $P$. tristriga (Möschler, 1890) (Noctuidae, Catocalinae).

\section{felina Herrich-Schäffer}

Emmelia felina Herrich-Schäffer, 1868: 151.

Material examined. One female type, "(57)".

Remarks. In very bad condition but recognizable. In VOB there are 5 specimens from Costa Rica, British Virgin Islands and Cuba. The Cuban females (VOB 73206) match Gundlach's specimen. The male from Costa Rica was compa- 
red with, and matches, Spragueia perstructana (Walker) in BMNH. E. felina was listed as an unrecognized species by HAMPSON (1910a: 804) and synonymized with $S$. perstructana by SCHAUS (1940: 215). This species is being treated in a forthcoming revision by WILTERDING (in press).

Identity. Spragueia felina (Herrich-Schäffer, 1868), a junior subjective synonym of $S$. perstructana (Walker, 1865) (Noctuidae, Acontiinae).

\section{fidelissima Herrich-Schäffer}

Composia fidelissima Herrich-Schäffer, 1866: 132.

Material examined. One male, 1 female, syntypes "(480/596)".

Remarks. In poor condition but recognizable. This species, beautifully illustrated on the cover of a book by KIMBALL (1965), has been correctly identified by all subsequent authors. A male from Cuba (VOB 73835), kindly presented to the author by Dr. P. Alayo, matches Gundlach's specimens.

Identity. Composia fidelissima Herrich-Schäffer, 1866 (Arctiidae, Ctenuchinae).

\section{grandirena Herrich-Schäffer}

Agrotis grandirena Herrich-Schäffer, 1868: 149.

Material examined. One male, 1 female, syntypes "(748)".

Remarks. The specimens are in bad condition but still recognizable. A. grandirena cannot be mistaken and is the species referred to by TODD \& POOLE (1980a) under this name.

In MNHU there is a female labelled: "Coll. H.-Sch. Cuba; Agr. disparilis "34". This could by a syntype. However, the only species name "disparilis" by Herrich-Schäffer, is Heterandra disparilis [= Euscirrhopterus poey Grote] an agaristine species that could never be confused with A. grandirena [see disparilis]. The only explanation is that Herrich-Schäffer changed his mind before describing the species.

Identity. Tiracola grandirena (Herrich-Schäffer, 1868) (Noctuidae, Hadeninae).

\section{guttula Herrich-Schäffer (Figs 7, 8, 32, 33)}

Celaeno guttula Herrich-Schäffer, 1868: 154.

Material examined. One female type "(402)".

Remarks. In very bad condition but recognizable. In VOB there is a series of specimens from Cuba (VOB 70372, 71108, 72076) (Figs 7, 8) that were compared with, and match, Gundlach's specimen. This species is closely related to Elaphria subobliqua (Walker, 1858) and mixed with this in BMNH and USNM. E. subobliqua [Type-locality: [Brazil]: Rio de Janeiro] seems to be restricted to the neotropical mainland whereas $C$. guttula to the Antilles. The former has broader wings and lacks the pair of coremata at the base of abdomen ventrally, present in C. guttula. C. guttula shows some phenotypic variation. Some specimens have the area distad of the postmedian line of the fore wings fuscous whilst in others, especially the females, this area is contrastingly white. Both forms can be sympatric and show no 


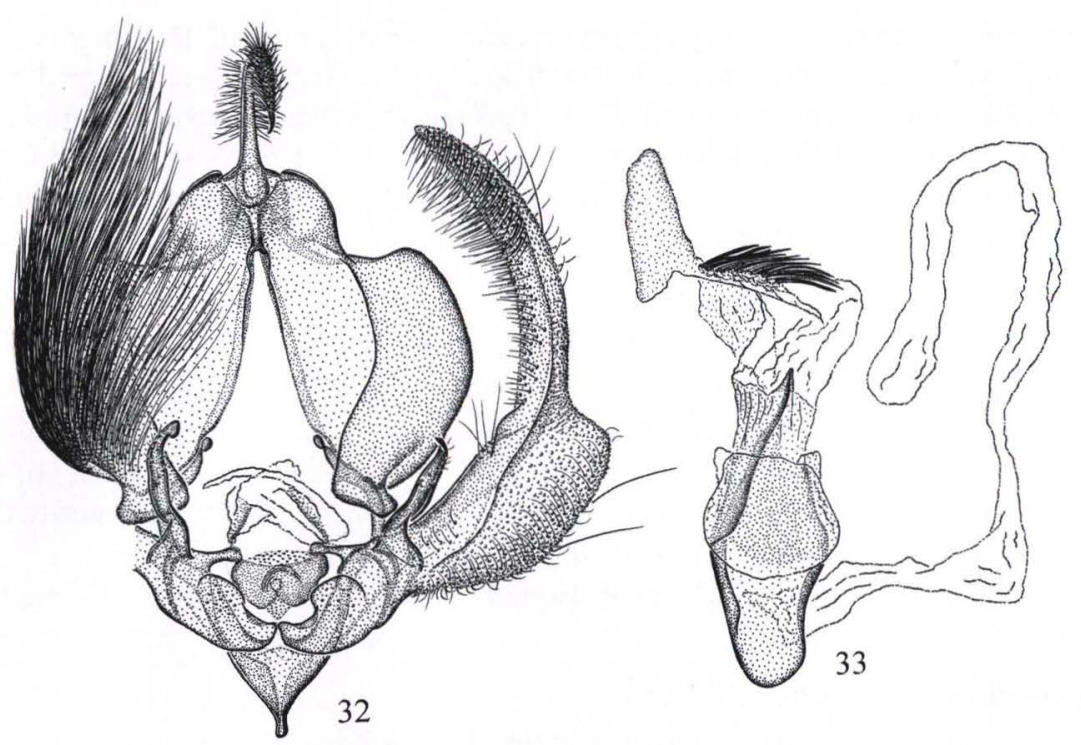

Figs 32-33. Elaphria guttula (Hadeninae) male genitalia. (32) ventral view, left valva and aedoeagus removed, (33) aedoeagus, ventral view.

difference in their genitalia (Figs 32,33). C. guttula was incorrectly synonymized with E. agrotina (Guenée, 1852) by HAMPSON (1909: 478).

Identity. Elaphria guttula (Herrich-Schäffer, 1868), sp. rev. (Noctuidae, Hadeninae).

\section{helveola Herrich-Schäffer}

Phurys helveola Herrich-Schäffer, 1869: 155.

Material examined. None traced.

Remarks. HAMPSON (1913: 117) treated P. helveola, apparently correctly, as a synonym of Nymbis helvina (Guenée). GuNDLACH (1881: 353) stated in his diagnosis that this form is "... muy parecida a la precedente [P. helvina], pero difiere por no tener el punto negro al lado del borde posterior del ala anterior" and has the same size "44 mil.". The series from Mexico, Costa Rica and Cuba in VOB contains specimens with and without the black dot.

Identity. Perasia helveola (Herrich-Schäffer, 1869), a junior subjective synonym of $P$. helvina (Guenée, 1852) (Noctuidae, Catocalinae).

inconspicua Herrich-Schäffer (Figs 4, 34, 35)

Leucania inconspicua Herrich-Schäffer, 1868: 148.

Material examined. One male type "(783)" [sic!].

Remarks. The code number "(783)" associated with the pin label "inconspicua" is certainly an error because in the original description and in GUNDLACH (1881: 301) the number stated is "(780)", and no "(783)" exists in the works of 


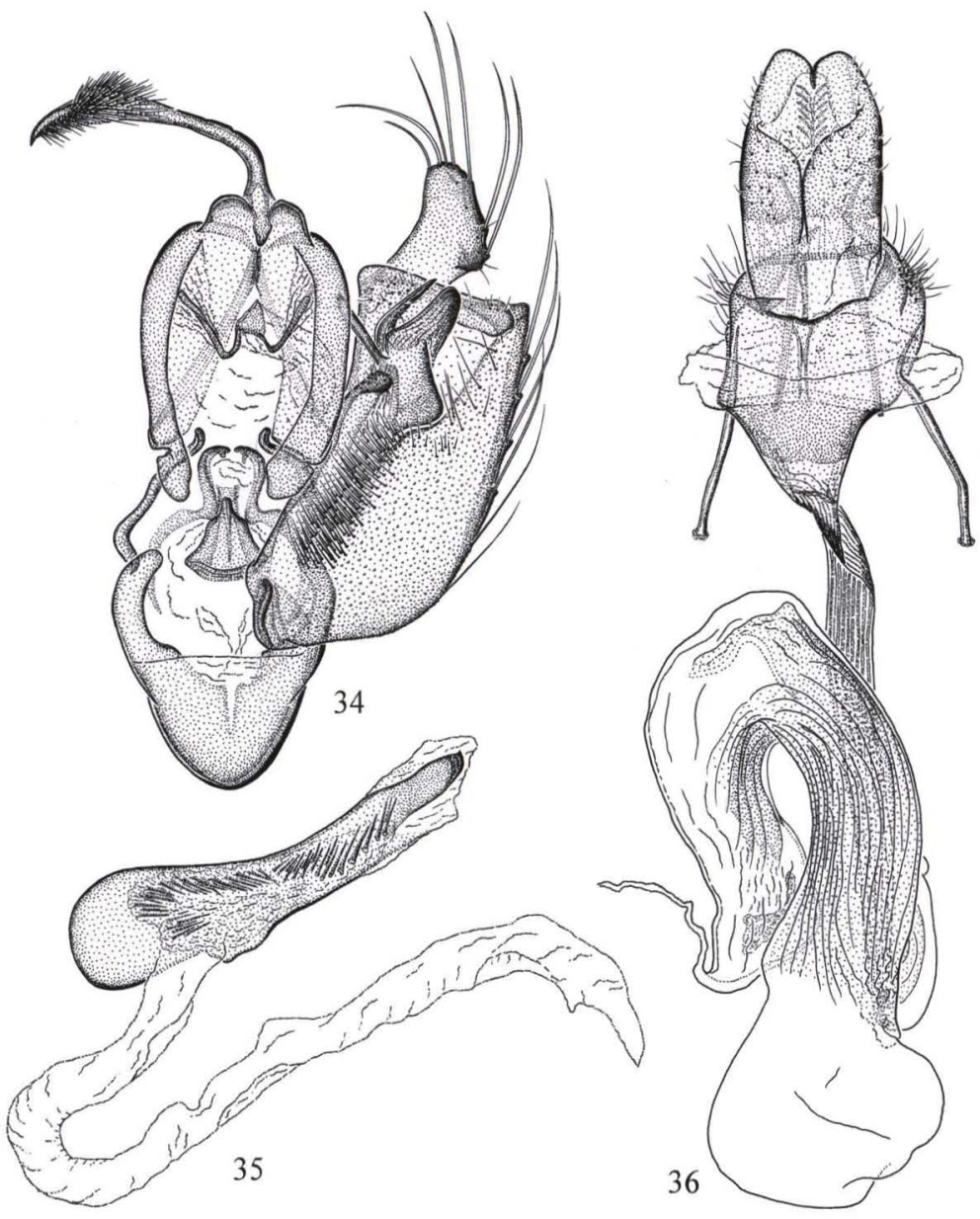

Figs 34-36. Leucania spp. (Hadeninae) genitalia. (34-35) L. inconspicua, male "Type". (34) ventral view, left valva and aedoeagus removed, (35) aedoeagus, lateral view; (36) L. latiuscula, female, "Type", ventral view.

Herrich-Schäffer and Gundlach. The specimen is in poor condition, almost totally descaled, and the hind wings are partially destroyed by museum pests. It is externally unrecognizable but the genitalia are preserved (Figs 34, 35). The genitalia of one male (VOB 73193), part of a series of 2 males and 3 females from Cuba (VOB 70043, 72068, 73193) (Fig. 4) match those of Gundlach's specimen and those of a male from Brazil (VOB 3379) that was compared with, and matches, the type of Cirphis hildrani Schaus, 1938, syn. n. in USNM. One female from Cuba (VOB 
70043) has genitalia identical to those of a female from Brazil (VOB 54810) which was compared, and match, the type of $C$. ezrami Schaus, 1938, syn. n. Redescribed and illustrated by HAMPSON (1905: 554, pl. XCIV, fig. 16), and ADAMS (2001: 192, figs $1 \mathrm{E}, 6 \mathrm{~A}-\mathrm{B}, 13 \mathrm{E})$.

Identity. Leucania inconspicua Herrich-Schäffer, 1868 (Noctuidae, Hadeninae).

\section{incrassata Herrich-Schäffer (Figs 37, 38)}

Plusia incrassata Herrich-Schäffer, 1868: 184.

Material examined. One male type "(1076)".

Remarks. Somewhat damaged and faded but still recognizable. A series of 8 specimens from Cuba (VOB 70074, 71146, 71662, 72341, 72571, 73215, 73421), was compared with, and matches, Gundalch's specimen and a series of $P$. calceolaris (Walker) in USNM. $P$. incrassata was listed as an unrecognized species by HAMPSON (1913: 594) and POOLE (1989: 815). The genitalia of a dissected male (VOB 72341) (Figs 37, 38) show the flat, apically not dentate, scales along the external margins of the valvae characteristic of Ctenoplusia Dufay (LAFONTAINE \& POOLE 1991: 46).

Identity. Ctenoplusia incrassata (Herrich-Schäffer, 1868), syn. n., a junior subjective synonym of $C$. calceolaris (Walker, [1858]), comb. n. (Noctuidae, Plusiinae).

\section{innata Herrich-Schäffer}

Plusia innata Herrich-Schäffer, 1868: 184.

Material examined. One male type "(86)".

Remarks. Faded and partially descaled, but recognizable. Correctly listed by HAMPSON (1913: 469) as a synonym of Trichoplusia ni (Hübner), the common "cabbage looper moth".

Identity. Trichoplusia innata (Herrich-Schäffer, 1868), a junior subjective synonym of T. ni (Hübner, [1803]) (Noctuidae, Plusiinae).

\section{insularis Herrich-Schäffer}

Tapinostola insularis Herrich-Schäffer, 1868: 148.

Material examined. None traced.

Remarks. The descriptions of Herrich-Schäffer "Habitus der Meliana [= Senta] flammea", and by GUNDLACH (1881: 302) "bermejizo-blanco. Las franjas de las alas anteriores y las alas posteriores son más blancas" clearly indicate that this is the species currently known as Simyra henrici Grote. Therefore Leucania henrici Grote, 1873, syn. n., L. evanida Grote, 1873, syn. n., Ablepharon fumosum Morrison, 1874, syn. n. and Ommatostolidea julithae Benjamin, 1933, syn. n., are junior subjective synonyms of $T$. insularis. HAMPSON (1909: 176) listed, under $S$. henrici, one male from Cuba in Grote's Coll. The zoologist Felipe Poey, who supplied Grote with Cuban material, also presented Gundlach with the specimen described by Herrich-Schäffer: "Recebi esta especie de mi amigo Poey.". Further Cuban specimens exist in IES and one male is in VOB (73858), kindly presented 
by Dr. P. Alayo. No other Cuban species can be confused with it. It was listed as an unrecognized species by HAMPSON (1910: 535) and POOLE (1989: 949).

Identity. Simyra insularis (Herrich-Schäffer, 1868), comb. n. (Noctuidae, Acronictinae).

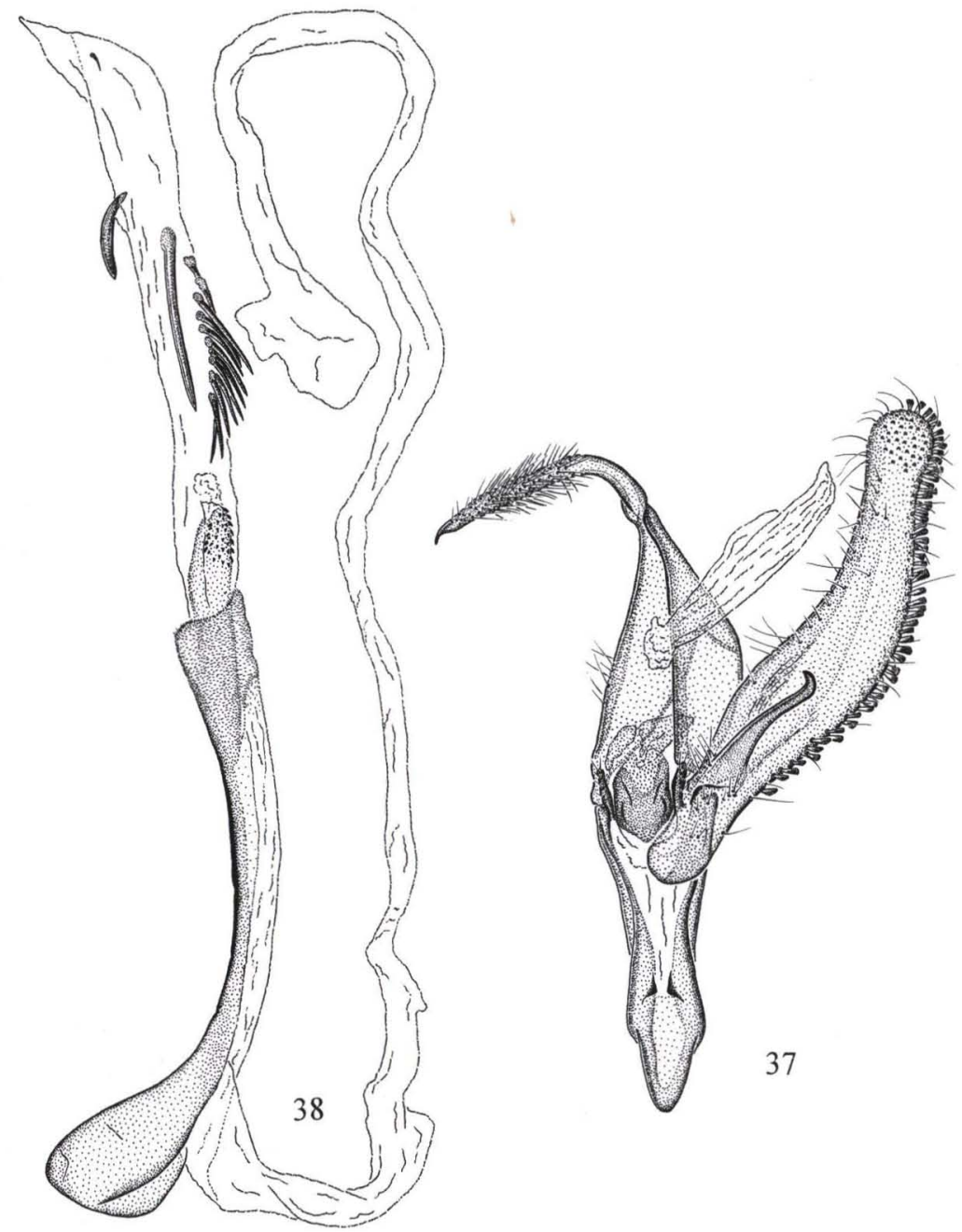

Figs 37-38. Ctenoplusia calceolaris [= incrassata] (Plusiinae) male genitalia. (37) ventral view, left valva and aedoeagus removed; (38) aedoeagus, lateral view. 


\section{latiuscula Herrich-Schäffer (Figs 3, 36)}

Leucania latiuscula Herrich-Schäffer, 1868: 148.

Material examined. One female type, "(281)".

Remarks. In poor condition, externally almost unrecognizable; hind wings almost completely destroyed by museum pests, but genitalia (Fig. 36) still preserved. In VOB there is a large series from Costa Rica, Brazil and Cuba. The genitalia of a Cuban female (VOB 70042) and of another female from Brazil (VOB 3346) match those of Gundlach's specimen. One of the Cuban males (Fig. 3) was compared with, and matches, the type of $L$. jaliscana Schaus, 1898, syn. n., in USNM. $L$. latiuscula sensu HAMPSON (1905: 542) and POOLE (1989: 581) is a different species currently known as L. subpunctata Harvey, 1875 (FERGUSON et al. 1991: 63; as subpuncta, missp.), ADAMS (2001: 184).

Identity. Leucania latiuscula Herrich-Schäffer, 1868 (Noctuidae, Hadeninae).

\section{leucomelana Herrich-Schäffer}

Bolina leucomelana Herrich-Schäffer, 1868186.

Material examined. Two females syntypes, "(583)".

Remarks. In reasonable condition, somewhat faded. This is only a form of Melipotis famelica (Guenée) [see striolaris]. One specimen from Cuba (VOB 71169) and one from the British Virgin Islands: Guana (VOB 66589) match Gundlach's specimens. M. famelica was illustrated by RICHARDS (1939: 15) and by BORDELON \& KNUDSON (1999: 32).

Identity. Melipotis leucomelana (Herrich-Schäffer, 1868), a junior subjective synonym of $M$. famelica (Guenée, 1852) (Noctuidae, Catocalinae).

\section{majuscula Herrich-Schäffer}

Orthodes majuscula Herrich-Schäffer, 1868: 148.

Material studied. None traced.

Remarks. There is only the pin bearing a label with the printed number "(796)" preserved. The original description and that of GUNDLACH (1881: 302), leave no doubt about the identity of this species. Orthodes is represented in Cuba by only two species: a small species with whitish hindwings, $O$. jamaicensis Hampson, 1905, and a large species with dark hind wings, O. majuscula. $O$. majuscula is widespread throughout the New World and Herrich-Schäffer mentioned, in the original description, that he also had specimens from the United States. In VOB there is a large series from Cuba, Mexico, Costa Rica, and Brazil. Specimens from this series were compared with the types of Dyschorista crenulata Butler, 1890, syn. n., and of Eriopyga vesquesa Dyar, 1913, syn. n. The genitalia of males from different localities show some slight differences, what is expected from a species with such a wide distribution. HAMPSON (1905: 613) listed O. majuscula as an unrecognized species, but treated $E$. crenulata. This species is illustrated, as $O$. crenulata, in KinBaLl (1965: pl. XII, fig. 4) and in Covell (1984: pl. 22, fig. 1). nae).

Identity. Orthodes majuscula Herrich-Schäffer, 1868 (Noctuidae, Hadeni- 


\section{minima Herrich-Schäffer}

Erastria minima Herrich-Schäffer, 1868: 132.

Material examined. One female type, "(403)".

Remarks. In bad condition, but recognizable. In IES there is a specimen labelled "Ote [Oriente, = Satiago], Cuabitas, jun. 1952 [P. Alayo]", identified as "C. metaspilaris". Both specimens match a male from the British Virgin Islands (VOB 73861), that agrees with both the description and illustration of Cobubatha metaspilaris (Walker) in HAMPSON (1910a: 317). E. minima was listed as an unrecognized species by HAMPSON (1910a: 804) and POOLE (1989: 368).

Identity. Cobubatha minima (Herrich-Schäffer, 1868), syn. n., a junior synonym of C. metaspilaris (Walker, 1863) (Noctuidae, Acontiinae).

\section{modestula Herrich-Schäffer (Fig. 21)}

Palindia modestula Herrich-Schäffer, 1869: 153.

Material examined. One male type, "(285)".

Remarks. In very bad condition; faded, hind wings and abdomen destroyed by museum pests, but still recognizable. A series from Cuba (VOB 700093, 70400, 71162, 71701, 72135) (Fig. 21) matches Gundlach's specimen and also material in USNM under the same name.

Identity. Eulepidotis modestula (Herrich-Schäffer, 1869) (Noctuidae, Catocalinae).

\section{nitidula Herrich-Schäffer (Fig. 25)}

Glaucopis nitidula Herrich-Schäffer, 1866: 114.

Material examined. None traced.

Remarks. In VOB there are two specimens from Cuba (VOB 70161) (Fig. 25 ) that match Gundlach's description. Similar to Eunomia insularis Grote, 1866, but easily recognized by the red vertex, which is white on that and on E. caymanensis Hampson, 1911, the two other species of the genus recorded to the island. HAMPSON (1898: 202) correctly placed E. nitidula in Eunomia Hübner, 1818, although the species was unknown to him, and apparently also unknown to DRAUDT (1915: 59).

Identity. Eunomia nitidula (Herrich-Schäffer, 1866) (Arctiidae, Ctenuchinae).

\section{obliquata Herrich-Schäffer}

Xanthoptera obliquata Herrich-Schäffer.

Material examined. One male type, "(508)".

Remarks. Very faded but recognizable. Three specimens from Cuba (VOB 73747) match Gundlach's specimen. The species was correctly interpreted by HAMPSON (1910a: 656).

Identity. Thioptera obliquata (Herrich-Schäffer, 1868) (Noctuidae, Acontiinae).

\section{ochricosta Herrich-Schäffer}

Ponometia ochricosta Herrich-Schäffer, 1868: 154.

Material examined. One female type "(61)".

Remarks. Badly damaged; hind wings destroyed by museum pests; forewings still with original pattern. This is the species correctly identified by 
HAMPSON (1910a: 680) as Graeperia costalis (Walker, [1858]) [= P. exigua Fabricius (FRANCLEMONT \& TODD 1983: 133)].

Identity. Ponometia ochricosta Herrich-Schäffer, 1868, a junior subjective synonym of $P$. exigua (Fabricius, 1793) (Noctuidae, Acontiinae).

\section{pallescens Herrich-Schäffer (Figs 39, 40)}

Trothisa pallescens Herrich-Schäffer, 1868: 154.

Material examined. One male type "(431)".

Remarks. In deplorable condition; externally unrecognizable, but with genitalia preserved (Figs 39, 40), matching those of a specimen from Mexico (VOB 68411) identified as E. recta (Guenée) by comparison with material in USNM. Correctly synonymized with $E$. obliqualis (Fabricius, 1794) [hom., = E. recta], by HAMPSON (1910a: 172).

Identity. Eublemma pallescens (Herrich-Schäffer, 1868), a junior subjective synonym of $E$. rectum (Guenée, 1852) (Noctuidae, Acontiinae).

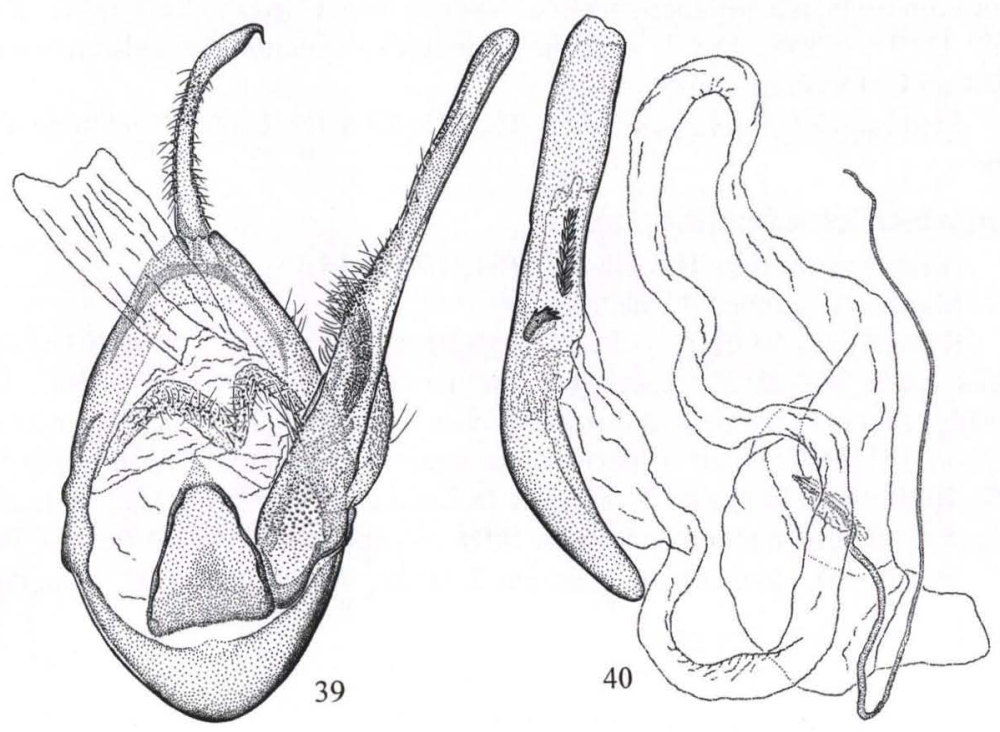

Figs 39-40. Eublemma rectum ["Type" of E. pallescens] (Acontiinae), male genitalia; (39) ventral view, left valva and aedoeagus removed; (40) aedoeagus, lateral view.

\section{pantherula Herrich-Schäffer}

Emmelia pantherula Herrich-Schäffer, 1868: 151.

Material examined. Two males syntypes, "(54)".

Remarks. In bad condition, one specimen unrecognizable, the other faded and partially destroyed by museum pests, but still recognizable. Correctly identified by HAMPSON (1910a: 662). A male from Cuba (VOB 72100) matches Gundlach's 
specimen. This species is being treated in a forthcoming revision by WILTERDING (in press).

Identity. Spragueia pantherula (Herrich-Schäffer, 1868) (Noctuidae, Acontiinae).

\section{parcicolor Herrich-Schäffer}

Bolina parcicolor Herrich-Schäffer, 1868: 186.

Material examined. Two females syntypes, "(187)".

Remarks. In reasonable condition: faded. Some specimens of this highly variable species show a strongly contrasting pattern whilst others are more uniform. Gundalch's specimens represent the latter form. In VOB there is a series of specimens from the British Virgin Islands, Puerto Rico and Cuba. Two Puerto Rican specimens (VOB 67404) and one from Cuba (VOB 66590) match Gundlach's specimens. One specimen from the British Virgin Islands (VOB 66590) was compared with, and matches, the type of Melipotis januaris (Guenée) in BMNH. Synonymized by SCHAUS (1940: 237) and illustrated in COVELL (1984: pl. 40, fig. 13 ) and in KIMBALL (1965: pl. XVII, figs 3, 4).

Identity. Melipotis parcicolor (Herrich-Schäffer, 1868), a junior subjective synonym of $M$. januaris (Guenée, 1852) (Noctuidae, Catocalinae).

\section{parvula Herrich-Schäffer}

Mamestra parvula Herrich-Schäffer, 1868: 118.

Material examined. Two males, 2 females syntypes "(560)".

Remarks. The 2 females badly damaged, unrecognizable; the 2 males in poor condition, faded, but still recognizable. Two males from Cuba (VOB 71123), from a series of 17 , were compared with, and match, Gundlach's specimens. TODD \& POOLE (1981: 187) stated that "the remnants of the wings of specimen "560" in National Museum of Cuba are now selected as the lectotype." However, none of the four specimens found has been labeled as such. Adult and genitalia illustrated in TODD \& POOLE (1981: 185-187).

Identity. Lacinipolia parvula (Herrich-Schäffer, 1868) (Noctuidae, Hadeninae).

\section{pectinata Herrich-Schäffer (Figs 41-43)}

Galgula pectinata Herrich-Schäffer, 1868: 152.

Material examined. One male type, "(948)".

Remarks. In bad condition, faded, left forewing missing, hind wings and abdomen partially destroyed by museum pests; distal half of both valvae destroyed (Figs 41-43). The genitalia, the wing pattern and the strongly serrate antennae match those of a specimen of Monodes cuprescens Hampson, 1909, syn. n., from the Dominican Republic (VOB 73863), the type-locality of M. cuprescens. POOLE (1989: 350) transferred M. cuprescens to Elaphria Hübner, 1818, however its genitalia are not congeneric with those of $E$. grata Hübner, 1818, the type species, but to those of $P$. xanthiodes Guenée, 1852, the type species of Perigea Guenée, 1852. G. pectinata was listed by HAMPSON (1910: 533) as an unrecognized species. Identity. Perigea pectinata (Herrich-Schäffer, 1868), comb. n. (Noctuidae, Hadeninae). 


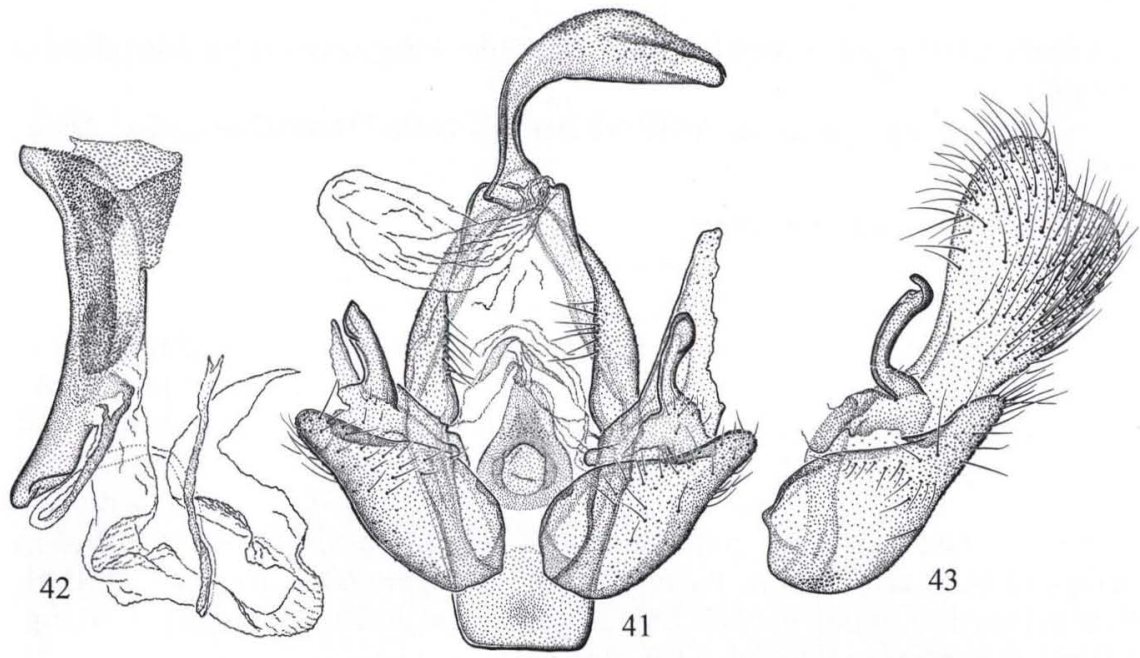

Figs 41-43. Perigea pectinata (Hadeninae) male genitalia. (41-42) "Type". (41) ventral view, valvae partially destroyed, aedoeagus removed; (42) aedoeagus, lateral view; (43) right valva, ventral view (Dominican Republic).

\section{penicillum Herrich-Schäffer}

Stictoptera penicillum Herrich-Schäffer, 1868: 185.

Material examined. One male, 1 female, syntypes, "(85)".

Remarks. Both specimens faded and somewhat descaled, but recognizable. One Cuban specimen (VOB 73037) was compared with, and matches, Gundlach's specimens; further specimens from Brazil, Mexico, and the British Virgin Islands were identified as Melipotis acontioides (Guenée) in BMNH and USNM. S. penicillum was correctly synonymized with M. acontioides by SCHAUS (1940: 236), but this synonymy was overlooked by Poole (1989), who transferred it to Nagara Walker, [1866]. Illustrated, as M. acontioides, in KIMBALL (1965: pl. XVII, fig. 9) and in BORDELON \& KNUDSON (1999: 32).

Identity. Melipotis penicillum (Herrich-Schäffer, 1868), syn. rev., a junior subjective synonym of $M$. acontioides (Guenée, 1852) (Noctuidae, Catocalinae).

plumbago Herrich-Schäffer (Figs 9, 44, 45)

Perigea plumbago Herrich-Schäffer, 1868: 118.

Material examined. One female "(40)'.

Remarks. In very bad condition, faded, hindwings and abdomen destroyed by museum pests, but recognizable. A series of specimens from Cuba (VOB 71111, 71613, 72278, 73197) (Fig. 9) was compared with, and matches, Gundlach's specimen. Incorrectly considered as a synonym of Condica concisa (Walker, 1856) by HAMPSON (1908: 330). Both are very similar in size and wing pattern, however, C. concisa has whitish hind wings whereas in P. plumbago they are dark, of the 
same color as the forewings. There are also differences in the male genitalia (Fig. 44, 45). Dr. R. Poole (pers. comm.) examined this figure and identified it as $C$. punctifera (Walker).

Identity. Condica plumbago (Herrich-Schäffer, 1868), syn. n., a junior subjective synonym of $C$. punctifera (Walker, [1857]). (Noctuidae, Condicinae).

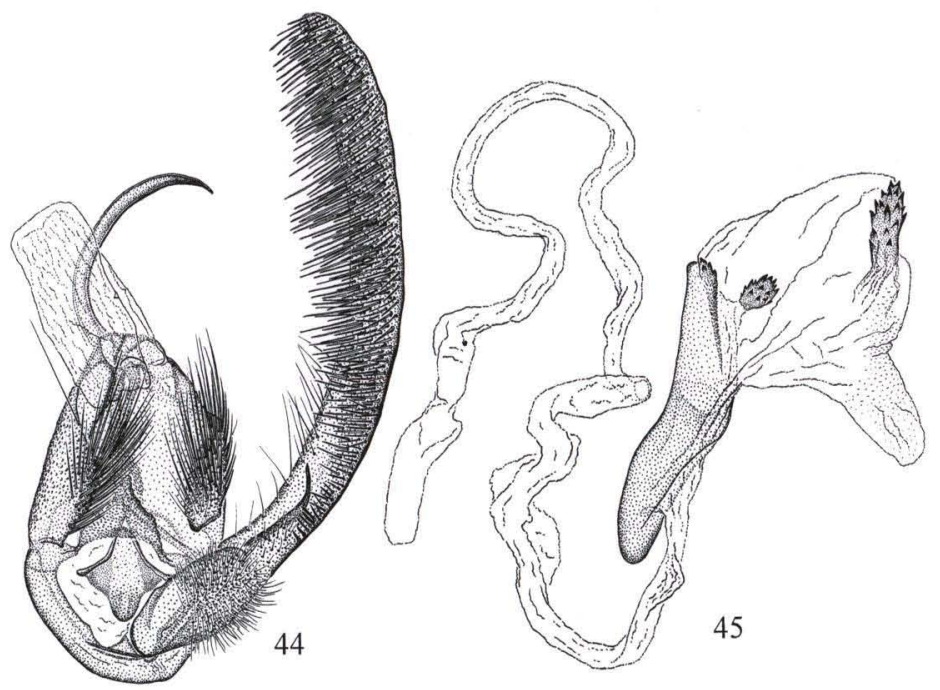

Figs 44-45. Condica punctifera [= plumbago] (Condicinae), male genitalia. (44) ventral view, left valva and aedoeagus removed; (45) aedoeagus, lateral view.

\section{plumosa Herrich-Schäffer}

Horamia [sic!] plumosa Herrich-Schäffer, 1866: 113.

Material examined. None traced.

Remarks. KIRBY (1892: 129) synonymized $H$. plumosa with $H$. pennipes (Grote); this was overlooked by HAMPSON (1898) but confirmed by DIETZ\& DUCKWORTH (1976: 15). According to HAMPSON (1898: 419) there are specimen(s) [of H. pennipes] in Coll. Staudinger (MNHU). If correct, this could be the material studied by Herrich-Schäffer. Both names were published in the same year; TODD (1966) established the priority of Grote's work.

Identity. Horama plumosa Herrich-Schäffer, 1866, a junior subjective synonym of $H$. pennipes (Grote) (Arctiidae, Ctenuchinae).

praeusta Herrich-Schäffer (Fig. 13)

"Nov. gen." praeusta Herrich-Schäffer, 1868: 180.

Material examined. One male type, "(436)".

Remarks. In poor condition; faded, and with hind wings partially destroyed by museum pests. Cuban specimens (VOB 71695, 72310) (Fig. 13) were compared with, and match, Gundlach's specimen; further specimens from the British Virgin 
Islands and Puerto Rico match males of Baniana relapsa (Walker) in BMNH and USNM. The name praeusta Herrich-Schäffer is a nomen nudum. GUNDLACH (1881: 327 ) listed it as praecesta, missp. Correctly synonymized with B. relapsa by Schaus (1940: 250).

Identity. Baniana relapsa (Walker, 1858) (Noctuidae, Catocalinae).

\section{pretellus Herrich-Schäffer}

Horamia [sic!] pretellus Herrich-Schäffer, 1866: 113.

Material examined. None traced.

Remarks. HAMPSON (1898: 422), who synonymized $H$. pretellus with $H$. diffissa Grote, examined Cuban specimens from Coll. Staudinger (MNHU). It is very likely that these were the specimens originally studied by Herrich-Schäffer. Both names were published in the same year; TODD (1966) established the priority of Grote's work. This synonymy was confirmed by DIETZ \& DUCKWORTH (1976: 17).

Identity. Horama pretellus Herrich-Schäffer, 1866, a junior subjective synonym of $H$. diffissa Grote, 1866 (Arctiidae, Ctenuchinae).

\section{pulchella Herrich-Schäffer}

Laphygma pulchella Herrich-Schäffer, 1868: 116.

Material examined. None traced.

Remarks. It seems that no author after GUNDLACH (1881: 292) has seen any of the original specimen(s): however, the interpretation of HAMPSON (1909: 243) appears to be correct. According to GUNDLACH (1881: 292) "El insecto perfecto se parece muchíssimo en su colorido a Pr. commelina [sic!] [= Spodoptera dolichos (Fabricius, 1794)] y es acaso solamente una veriedad menor, pues tiene entre las alas 32 mil.". And, amongst the New World species L. pulchella resembles $S$. dolichos most closely. TODD \& POOLE (1980) give a key with good illustrations of the adults and genitalia for all the New World species in the genus.

Identity. Spodoptera pulchella (Herrich-Schäffer, 1868) (Noctuidae, Hadeninae).

\section{purpurascens Herrich-Schäffer (Figs 10, 46)}

"Nov. gen." purpurascens Herrich-Schäffer, 1868: 182.

Material examined. One male, 1 female, syntypes, "(601)".

Remarks. Almost totally destroyed; externally unrecognizable, but the female genitalia (Fig. 46) are still preserved and match those of a specimen also from Cuba (VOB 71183). This and other specimens in the series (VOB 71183, 71692, 72313) (Fig. 10) match the description of GUNDLACH (1881: 330) and material of Parachabora triangulifera Hampson in USNM. The name purpurascens HerrichSchäffer, syn. n., is a nomen nudum.

Identity. Parachabora triangulifera Hampson, 1901 (Noctuidae, Catocalinae).

\section{rectifascia Herrich-Schäffer}

Bolina rectifascia Herrich-Schäffer, 1868: 186.

Material examined. None traced.

Remarks. Both the original description and the diagnosis in GUNDLACH 
(1881: 342) indicate that this name refers to the strongly marked form of Melipotis januaris (Guenée, 1852), as previously recognized by SCHAUS (1940: 237) [see parcicolor].

Identity. Melipotis rectifascia (Herrich-Schäffer, 1868), a junior subjective synonym of $M$. januaris (Guenée, 1852) (Noctuidae, Catocalinae).

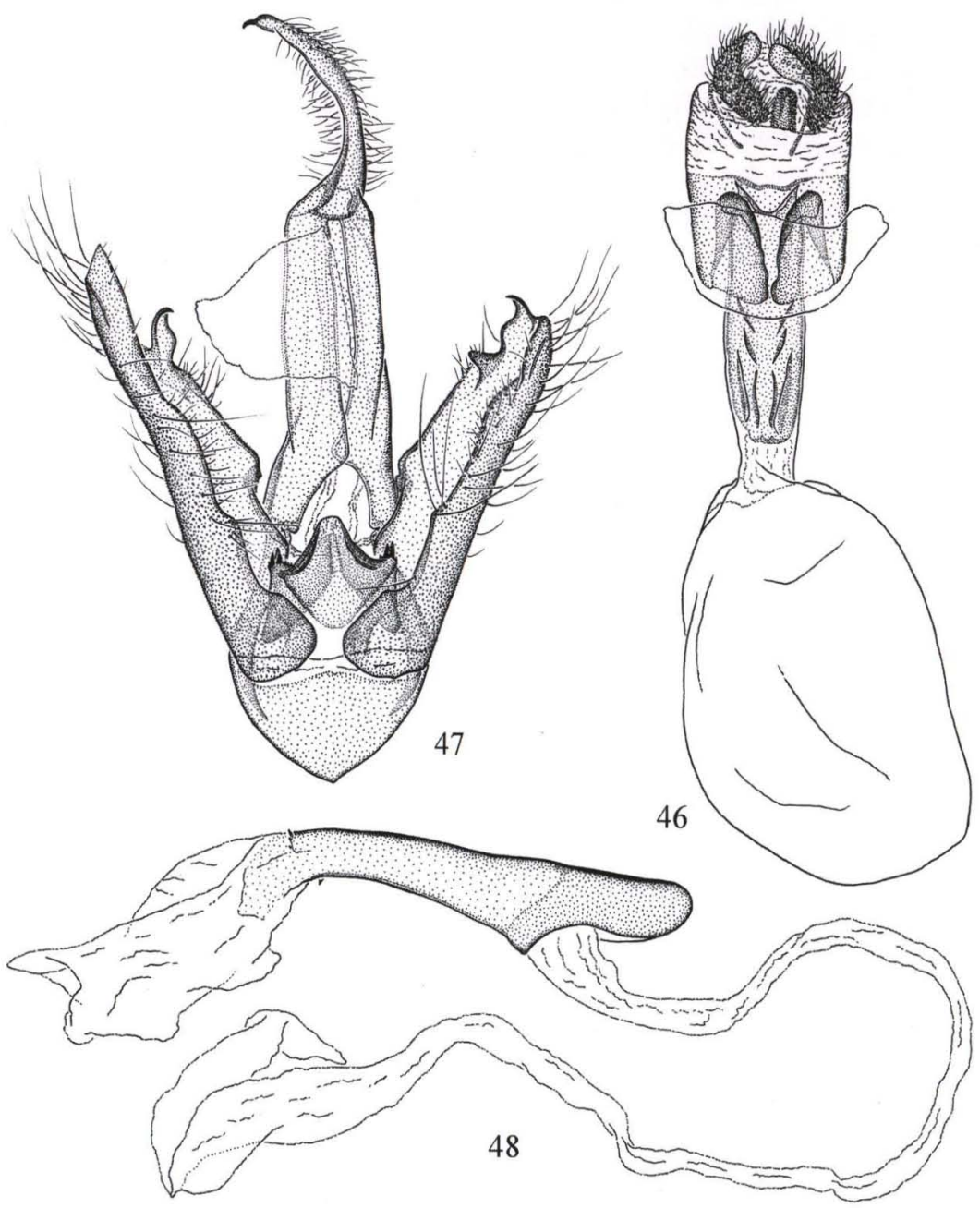

Figs 46-48. Catocalinae genitalia. (46) Parachabora triangulifera ["Type" of $P$. purpurascens], female, ventral view; (47-48) Phyprosopus tristriga: (47) male, ventral view, aedoeagus removed; (48) aedoeagus, lateral view. 
reflexa Herrich-Schäffer (Fig. 27)

Palindia reflexa Herrich-Schäffer, 1869: 154.

Material examined. None traced.

Remarks. This species has remained unrecognized since GUNDLACH (1881: 347). DYAR (1914: 112), stated that "Recently Mr. Schaus and the writer, in considering the identification of Herrich-Schäffer's name, have concluded that it is probably not a Palindia [=Eulepidotis] at all, or even a Noctuid, but is an earlier name for Paridnea holophealis Ragonot, 1892, a Pyralid of the subfamily Chrysauginae”. PoOLE (1989: 406) included P. reflexa in Eulepidotis Hübner, 1823, the senior synonym of Palindia Guenée, 1852, apparently overlooking Dyar's oppinion. Solís et al. (1995: 86) retained it as a valid species in Paridnea Ragonot, 1892, following the curation of the Chrysauginae collection in USNM. This decision seems not correct either as no species of Paridnea has been recorded to the Antilles (BECKER, in prep.). The description given by GUNDLACH (1881: 347), especially that of the male "El macho difiere por su tamaño menor y un lóbulo semicircular blanco con orillas rojizas, doblado sobre el ala" indicates that the species is Lepidomys irrenosa Guenée, a pyralid also originally described as a Noctuidae. No other Antillean moth (Fig. 27) bears this "white semicircular lobe" on forewings.

Identity. Lepidomys reflexa (Herrich-Schäffer, 1868), syn. n., a junior subjective synonym of $L$. irrenosa Guenée, 1852 (Pyralidae, Chrysauginae).

\section{rotundata Herrich-Schäffer (Fig. 20)}

Epidromia rotundata Herrich-Schäffer, 1869: 159.

Material examined. One male type, "(292)".

Remarks. In reasonable condition, faded. Cuban specimens (VOB 71191, 72032, 72573, 73222) (Fig. 25) match Gundlach's specimen, and the genitalia of one of them matches those of E. lienaris (Hübner), an extremely variable species which has been described at least 10 times (BECKER 2001:). Also illustrated, as $E$. pannosa Guenée, 1852, in Solís (1986).

Identity. Epidromia rotundata Herrich-Schäffer, 1869, a junior subjective synonym of E. lienaris (Hübner, 1823) (Noctuidae, Catocalinae).

\section{secta Herrich-Schäffer (Fig. 2)}

Leucania secta Herrich-Schäffer, 1868: 147.

Material examined. None traced.

Remarks. There is only a label "(777)" on the pin. In Cuba there are only two species of Leucania, almost the same size and very similar to each orther. One of them (Fig. 2), as GUNDLACH (1881: 300) described it, "El insecto perfecto tiene un color rojizo claro...... Las alas posteriores son blancas", and the other with the ground colour of both wings lemon yellow. The first is the true $L$. secta $[=L$. clarescens sensu HAMPSON (1905: 519, pl. XCII, fig. 21), misid., = Cirphis hampsoni Schaus, 1940] (ADAMS 2001: 205). The second, secta sensu HAMPSON (1905: 524, pl. XCII, fig. 27) was described as L. educata by ADAMS (2001: 208).

Identity. Leucania secta Herrich-Schäffer, 1868 (Noctuidae, Hadeninae). 


\section{selecta Herrich-Schäffer}

Laemocharis selecta Herrich-Schäffer [1854]: fig. 256.

Material examined. One male, 1 female, "(71)".

Remarks. In poor condition but recognizable. These specimens are not part of the type-material as Herrich-Schäffer did not study Gundlach's material until 1860. According to HAMPSON (1914: 125) the "type" is in Coll. Oberthür (BMNH). In VOB there is a series of 14 specimens from Puerto Rico and Cuba. The Cuban specimens match Gundalch's material; the Puerto Rican are identified as Phoenicoprocta capistrata (Fabricius) in USNM.

Identity. Phoenicoprocta selecta (Herrich-Schäffer, [1854]), a junior subjective synonym of $P$. capistrata (Fabricius, 1775) (Arctiidae, Ctenuchinae).

\section{striolaris Herrich-Schäffer}

Bolina striolaris Herrich-Schäffer, 1868: 186.

Material examined. One male, 1 female, syntypes "(92)".

Remarks. Both specimens faded and partially destroyed by museum pests, but recognizable. In VOB there is a series of specimens from the British Virgin Islands, Puerto Rico and Cuba. The Cuban specimens (VOB 70100, 70761, 71169, 72115) were compared with, and match, Gunclach's specimens. The others were identified as Melipotis famelica (Guenée) by comparizon with material in BMNH and USNM. SCHAUS (1940: 236) incorrectly listed B. striolaris as a synonym of $M$. contorta (Guenée, 1852) [see leucomelana].

Identity. Melipotis striolaris (Herrich-Schäffer, 1868), syn. n., a junior subjective synonym of M. famelica (Guenée, 1852) (Noctuidae, Catocalinae).

\section{submuscosa Herrich-Schäffer}

Agrotis submuscosa Herrich-Schäffer, 1868: 149.

Material examined. None traced.

Remarks. The large size "48 mil.", and the description by GUNDLACH (1881: 308): "El cuello y el borde anterior de las piezas humerales son negruzcos", best fit A. repleta Walker. A. submuscosa was listed by HAMPSON (1903: 666) as an unrecognized species and incorrectly considered a junior synonym of A. malefida Guenée, 1852, by ScHaus (1940: 180).

Identity. Agrotis submuscosa Herrich-Schäffer, 1868, syn. n., a junior subjective synonym of $A$. repleta Walker, 1857 (Noctuidae, Noctuinae).

\section{subochrea Herrich-Schäffer}

Correbia subochrea Herrich-Schäffer, 1866: 115.

Material examined. None traced.

Remarks. There is only a pin with Gundlach's label "(363/157)". C. subochrea was incorrectly synonymized with $C$. lycoides (Walker) by HAMPSON (1898: 515) [see bicolor].

Identity. Correbidia subochrea (Herrich-Schäffer, 1866), syn. n., a junior subjective synonym of Correbidia terminalis (Walker, 1856) (Arctiidae, Ctenuchinae). 


\section{trapezoides Herrich-Schäffer}

Celaeno trapezoides Herrich-Schäffer, 1868: 153.

Material examined. One female type, "(683)".

Remarks. Faded and slightly damaged by museun pests, but recognizable. Cuban specimens (VOB 70370, 71109, 71626, 72079) were compared with, and match, Gundlach's specimen; identical specimens from Brazil were identified as Gonodes liquida (Möschler) by comparison with material in BMNH and USNM. Therefore Ipimorpha liquida Möschler, 1886, syn. n., Drobeta leada Druce, 1898 , syn. n. and Cyatissa violascens Schaus, 1894, syn. n. are junior subjective synonyms of $C$. trapezoides. This species was incorrectly synonymized with Monodes subobliqua (Walker, 1858) by HAMPSON (1909: 479) [see guttula].

Identity. Gonodes trapezoides (Herrich-Schäffer, 1868), comb. n., sp. rev. (Noctuidae, Hadeninae).

\section{trichroma Herrich-Schäffer}

Hadena trichroma Herrich-Schäffer, 1868: 116.

Material studied. Two males syntypes, "(596)".

Remarks. Faded and partially destroyed by museum pests but recognizable. Eight specimens from Cuba (VOB 71619, 72088, 72282) were compared with, and match Gundlach's specimens. H. trichroma was correctly described and illustrated by HAMPSON (1908: 256, pl. CXIV, fig. 24).

Identity. Speocropia trichroma (Herrich-Schäffer, 1868) (Noctuidae, Hadeninae).

\section{tricolor Herrich-Schäffer (Figs 23, 24)}

Torycus tricolor Herrich-Schäffer, 1866: 199.

Material examined. One female type, "(60)" and 1 male "(775)".

Remarks. Both in poor condition; destroyed by museum pests, except for the head, thorax and a few wing veins; unrecognizable. The male has no type-status as GUNDLACH (1881: 254) stated that "El ejemplar que servió para la descripcion dada por Herrich-Schäffer es hembra. Al mismo tiempo mandé un macho que difiere por vários caracteres que probablemente serán difierencias sexuales.". A series of 16 specimens from Cuba (VOB 70740, 71071, 71592) (Figs 23, 24) matches the descriptions of Herrich-Schäffer and Gundlach. All females, but none of the males, have a white dot in the middle of the forewings as described. The intensity of pink on the head, patagia and dorsum of forewings varies; in some specimens these areas are almost white. One male (VOB 71592) was compared with, and matches, the type of Boenasa toryca Schaus, 1924, syn. n., in USNM. SCHAUS (1924: 30) stated that "In Torycus the venation of the fore wing is similar to Boenasa Walker, [1865], but the hind wings have all the veins present". This statement is valid only for the females, because the males of $T$. tricolor have the hind wing venation reduced, and folded in a peculiar way as described by HAMPSON (1900: 554) for Boenasa, leaving no doubt that Torycus Herrich-Schäffer, 1866, syn. n. is a junior subjective synonym of Boenasa Walker, [1865].

Identity. Boenasa tricolor Herrich-Schäffer, 1866, comb. n. (Arctiidae, Lithosiinae). 


\section{trigridula Herrich-Schäffer}

Emmelia trigridula Herrich-Schäffer, 1868: 151.

Material examined. Two males syntypes "(56)".

Remarks. In very bad condition; one unrecognizable; the other still recognizable. In VOB there are five specimens, three of them from Costa Rica (VOB 33147), one from the British Virgin Islands (VOB 70728) and one from Cuba (VOB 73206). The last two were compared with, and match, Gundlach's specimen; the Costa Rican was identified as Spragueia perstructana (Walker) by comparison with material in BMNH. Listed as an unrecognized species by HAMPSON (1910a: 804) and as a synonym of $S$. perstructana by FRANCLEMONT \& TODD (1983: 134) [as tigridula, missp.] [see also felina].

Identity. Spragueia trigridula (Herrich-Schäffer, 1868), a junior subjective synonym of $S$. perstructana (Walker, 1865) (Noctuidae, Acontiinae).

\section{tristriga Herrich-Schäffer (Figs 15, 16, 47, 48)}

"Nov. gen." tristriga Herrich-Schäffer, 1868: 181.

Material examined. One male type "(570)".

Remarks. Faded, hind wings partially destroyed by museum pests. HERRICH-SCHÄFFER (1868: 181) described three different forms of this highly variable species: albigutta, fastigiata and tristriga. GUNDLACH (1881: 329) correctly stated "He enumerado las especies del género, conforme las tiene H. Schäffer, aunque me inclino a considerarlas com variedades de una sola especie. Acaso más ejemplares lo probarán." This synonymy has been accepted by SCHAUS (1940: 260) and by WOLCOTT (1951: 618) who reared the species and stated that "The moths exhibit considerable variation in appearance..."; this was overlooked by POOLE (1989: 802). In VOB there is a series of 11 specimens, 9 of them from Cuba; one of the latter (VOB 71177) (Fig. 16) matches Gundlach's specimen. The three Herrich-Schäffer names are nomina nuda, but tristriga was subsequently made available by MöSCHLER (1890: 178) as Pseudocalpe tristriga. The male genitalia (Figs 47,48) from specimens representing the different forms are identical.

Identity. Phyprosopus tristriga (Möschler, 1890), comb. n. (Noctuidae, Catocalinae).

\section{uncinula Herrich-Schäffer}

Emmelia uncinula Herrich-Schäffer, 1868: 151.

Material examined. None traced.

Remarks. The diagnosis given by GUNDLACH (1881: 314) "El insecto es negruzco, las alas anteriores en su borde anterior, tiene 3 manchitas blancas, la intermedia cuadrada. Entre las alas 17 mil." indicates that it is the form correctly recognized by HAMPSON (1910a: 662) as the female of E. pantherula [see pantherula].

Identity. Spragueia uncinula (Herrich-Schäffer, 1868), a junior subjective synonym of $S$. pantherula (Herrich-Schäffer, 1868) (Noctuidae, Acontiinae). 

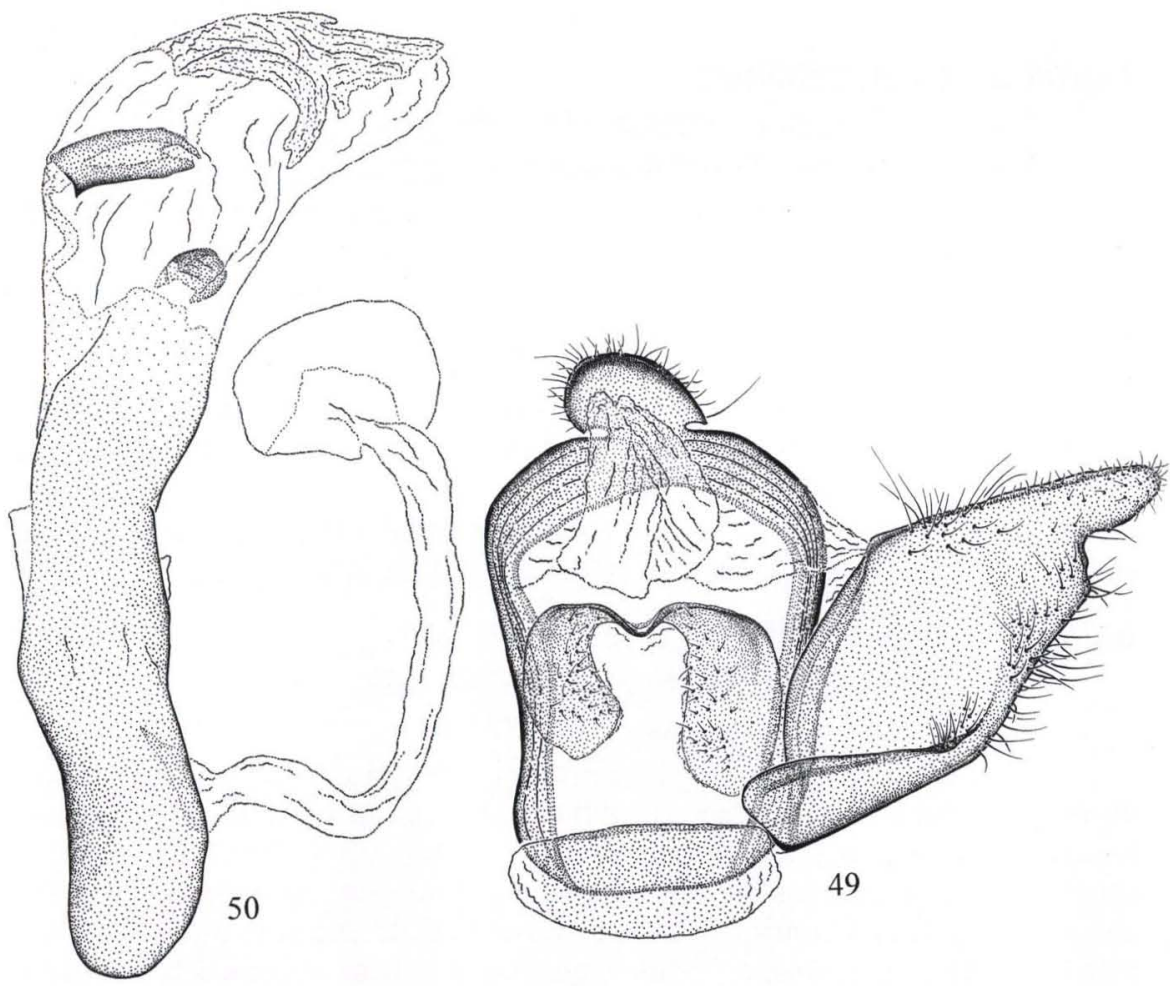

Figs 49-50. Syntomeida wrighti (Ctenuchinae) male genitalia. (49) ventral view, left valva and aedoeagus removed; (50) aedoeagus, lateral view.

wrighti Gundlach (Figs 26, 49, 50)

Hippola? wrighti Gundlach, 1881: 243.

Material examined. One female "1057)".

Remarks. In poor condition; wings almost totally destroyed by museum pests; however, the abdomen still preserves the conspicuous marks. Four specimens from Cuba (VOB 71589) (Fig. 26) were compared with, and match, Gundlach's specimen. HAMPSON (1898: 306) incorrectly synonymized $H$. wrighti with Syntomeida syntomoides (Boisduval, 1836). It was described again as Eurota [sic!] parishi Rothschild, 1911, syn. n. Its genitalia (Figs 49, 50), however, are very different from those of Eurata picta Herrich-Schäffer, [1853], the type-species of this genus, and closely resemble those of $S$. syntomoides.

Identity. Syntomeida wrighti (Gundlach, 1881), comb. n., sp. rev. (Arctiidae, Ctenuchinae).

No Gundlach material of the following species was found at the IES. According to GUNDLACH (1881: 374) it was never returned to him. It is very likely that at least part of it is deposited in the (MNHU) among other Herrich-Schäffer's material. 
Physula acutalis Herrich-Schäffer, 1870: 107.

Physula albirenalis Herrich-Schäffer, 1870: 106.

Physula apicalis Herrich-Schäffer, 1870: 107.

Hemeroplanis apicigutta Herrich-Schäffer, 1869: 160.

Capnodes costaeluna Herrich-Schäffer, 1870: 97.

Physula costigutta Herrich-Schäffer, 1870: 107.

"N. g." distigmula Herrich-Schäffer, 1870: 108.

Matigophora gracillima Herrich-Schäffer, 1870: 106.

Physula herminialis Herrich-Schäffer, 1870: 107.

Capnodes inconspicua Herrich-Schäffer, 1870: 97.

Palindia inferior Herrich-Schäffer, 1869: 153.

Mastigophora latipennis Herrich-Schäffer, 1870: 105.

Tortricodes nigrirena Herrich-Schäffer, 1870: 108.

Capnodes punctistriga Herrich-Schäffer, 1870: 97.

Palindia striaepuncta Herrich-Schäffer, 1869: 153..

"Nov. gen." subapicalis Herrich-Schäffer, 1869: 160.

Mastigophora terminalis Herrich-Schäffer, 1870: 105.

Physula tristrigalis Herrich-Schäffer, 1870: 107.

Physula tuberculata Herrich-Schäffer, 1870: 106.

Physula variegalis Herrich-Schäffer, 1870: 106.

Capnodes versicolor Herrich-Schäffer, 1870: 97.

Itonia [sic!] xylina Herrich-Schäffer, 1869: 157. (VOB 71678, Fig. 17).

\begin{abstract}
ACHNOWLEDGEMENTS. The present work would not have been possible without the collaboration of the staff of the IES, its Directors: Biol. Pedro Pérez and Biol. Ada Camacho, and the following staff members who gave all the support either in the laboratory or, especially, by companionship and help in the field: Dr. Rafael Alayo, Biol. Luiz de Armas, Biol. Eduviges Valdés, Biol. Melba Hernández, and to Mr. Pedro Ortega. I am particularly idebted to Dr. Pastor Alayo who provided me with much useful information related to this project and supplied several specimens that filled gaps in my collection; and to his wife Blanca, for the kindness she showed to me during several visits to their home. Finally to those who read and presented several corrections and suggestions that improved this work significantly: Dr. Robert Poole, USNM, and Dr. Klaus Sattler, BMNH. Mr. W. Cavalcanti, EMBRAPA-CPAC, Planaltina, DF, Brazil, made the line drawings.
\end{abstract}

\title{
REFERENCES
}

AdAMS, M.S. 2001. A revision of the moth genus Leucania Ochsenheimer in the Antilles (Insecta: Lepidoptera: Noctuidae). Ann. Carneg. Mus. 70: 179-220.

BeCKer, V.O. 2001. The identity of Hemeroblemma lienaris Hübner and a review of the neotropical moths of the pannosa-complex of Epidromia Guenée (Noctuidae, Catocalinae). Revta bras. Zool. 18: 961-964.

Bordelon JR., C. \& E. KnUdSon. 1999. Noctuidae from Texas: The genus Melipotis and related or similar genera. News Lepid. Soc. 41: 32-34. 
Covell, C.V. 1984. A field guide to the moths of Eastern North America. The Peterson Field Guide Series. Boston, Houghton Mifflin. 496p.

Dietz, R.E. \& W.D. DuckworTh. 1976. A review of the genus Horama Hübner and reestablishment of the genus Poliopastea Hampson (Lepidoptera: Ctenuchidae). Smithson. Contr. Zool. 215: 1-53.

Druce, H. 1884-1885. Arctiidae, p. 69-119. In: F.D. Godman \& O. Salvin (Eds). Biol. Centr.-Amer., Zool. Lepidopt.-Heterocera 1.

- 1891-1900. Supplement. In: F.D. Godman \& O. Salvin (Eds). Biol. Centr.-Amer., Zool. Lepidopt.-Heterocera 2, p. 298-566.

Draudt, M. 1915. Syntomidae, p. 33-230. In: A. Seitz (Ed.). Die Gross Schmetterlinge der Erde. 6. Stuttgart, Kernen, 1452p.

Dyar, H.G. 1914. The noctuid moths of the genera Palindia and Dyomyx. Proc. U.S. nat. Mus. 47: 95-116.

Ferguson, D.C.; D.J. Hilburn \& B. Wright. 1991. The Lepidoptera of Bermuda: Their food plants, biogeography, and means of dispersal. Mem. Ent. Soc. Can. 158: 1-105.

FIELD, W.D. 1951. Moths of the genus Paramulona Hampson. Proc. U.S. nat. Mus. 101: 489-496.

Franclemont, J.G. \& E.L. Todd. 1983. Noctuidae, p. 120-159. In: R.W. Hodges; T. Dominick; D.R. Davis; D.C. Ferguson; J.G. Franclemont; E.G. Munroe \& J.A Powell (Eds). Check list of the Lepidoptera of America North of Mexico. London, Classey \& Wedge Entomological Research Foundation, 284p.

Grote, A.R. 1866. Notes on the Zygaenidae of Cuba. Proc. ent. Soc. Phil. 6: 173-189.

Gundlach, J.C. 1881. Contribución a la Entomologia Cubana. Habana, G. Montiel, 445p.

Hampson, G.F. 1898. Catalogue of the Lepidoptera Phalaenae in the British Museum I. London, British Museum, 559p.

. 1900. Catalogue of the Lepidoptera Phalaenae in the British Museum II. London, British Museum, 589p.

- 1903. Catalogue of the Lepidoptera Phalaenae in the British Museum IV. London, British Museum, 689p.

- 1905. Catalogue of the Lepidoptera Phalaenae in the British Museum V. London, British Museum, 634p.

- 1905a. Descriptions of new species of Noctuidae in the British Museum. Ann. Mag. nat. Hist. 7 (16): 369-386.

. 1908. Catalogue of the Lepidoptera Phalaenae in the British Museum VII. London, British Museum, 709p.

. 1909. Catalogue of the Lepidoptera Phalaenae in the British Museum VIII. London, British Museum, 583p.

- 1910. Catalogue of the Lepidoptera Phalaenae in the British Museum IX. London, British Museum, 552p.

. 1910a. Catalogue of the Lepidoptera Phalaenae in the British Museum X. London, British Museum, 829p.

- 1912. Catalogue of the Lepidoptera Phalaenae in the British Museum XI. London, British Museum, 689p.

. 1913. Catalogue of the Lepidoptera Phalaenae in the British Museum XIII. London, British Museum, 609p.

- 1914. Catalogue of the Lepidoptera Phalaenae in the British Museum Supplement I. London, British Museum, 858p.

- 1920. Catalogue of the Lepidoptera Phalaenae in the British Museum Supplement II. London, British Museum. 619 p.

HERRICH-SCHÄFFER, G.A.W. 1854. Sammlung neuer oder wenig bekannter aussereuropäischer Schmetterlinge I. Regensburg, G. J. Manz. Heft 12.

- 1866. Schmetterlinge aus Cuba. CorrespBl. zool.-min. Ver. Regensburg 20: 103-109, 113-120, 130-136. 
1868. Die Schmetterlinge der Insel Cuba. CorrespBI. zool.-min. Ver. Regensburg 22: 113-118, 147-156, 179-186. $153-160$

1869. Die Schmetterlinge der Insel Cuba. CorrespBl. zool.-min. Ver. Regensburg 23: . 1870. Die Schmetterlinge der Insel Cuba. CorrespBl. zool.-min. Ver. Regensburg 24: 97-108.

KimbalL, C.P. 1965. Arthropods of Florida and neighboring land areas. I. Lepidoptera of Florida. Gainesville, Florida Department of Agriculture, 363p.

KIRBY, W.F. 1892. A synonymic catalogue of Lepidoptera Heterocera-moths. I. London, Taylor \& Francis, 952p.

Lafontaine, J.D. \& R.W. Poole. 1991. Noctuoidea, Noctuidae (Part), Plusiinae. In: R.B. Dominick; R.W. Hodges; D.R. Davis; T. Dominick; D.C. Ferguson; J.G. Franclemont; Eugene G. Munroe \& J.A. PoweLl (Eds). The moths of America North of Mexico, fasc. 25.1. Washington, DC, Wedge Entomological Research Foundation, 182p.

MösChLER, H.B. 1890. Die Lepidopteren-Fauna der Inseln Porto Rico. Abh. senckenb. naturforsch. Ges. 16: 7-360.

Poole, R.W. 1989. Noctuidae. Lepid. Cat. (new series) 118: 1-1013.

RichARDS, A.G. 1939. A revision of the Phoberia-Melipotis-Drasteria group of moths (Lepidoptera, Phalaenidae). Entomologica am. 19: 1-100.

Schaus, W. 1924. New species of moths in the United States National Museum. Proc. U.S. Nat. Mus. 65: $1-74$.

- 1940. Noctuidae. Scient. Surv. P. Rico 12: 177-290.

Solís, M.A. 1986. A new species of Epidromia (Noctuidae) from Florida. Jour. Lepid. Soc. 40: 8-19.

Solís, M.A.; V.O. BeCKer \& E. Munroe. 1995. Chrysauginae. In: J.B. HePpNer (Ed.). Atlas of neotropical Lepidoptera. 2. Gainesville, Association for Tropical Lepidoptera. pp. 81-88.

ToDD, E.L. 1964. Nomenclatural and descriptive notes on Orodesma apicina H.-S. and its subspecies (Lepidoptera, Noctuidae). Proc. biol. Soc. Wash. 77: 65-71.

. 1966. Notes and descriptions of some neotropical agaristine moths (Lepidoptera: Noctuidae). Prc. U.S. Nat. Mus. 120: 1-15.

TodD, E.L. \& R.W. Poole. 1980. The American species of the Tiracola plagiata Walker complex (Lepidoptera: Noctuidae: Hadeninae). Proc. ent. Soc. Wash. 82: 396-400.

. 1980a. Keys and illustrations for the armyworm moths of the noctuid genus Spodoptera Guenée from the Western Hemisphere. Ann. ent. Soc. Amer. 73: 722-738.

. 1981. Moths of the parvula complex of Lacinipolia McDunnough (Noctuidae: Hadeninae).

Fla. ent. 64: 183-189.

Wolcott, G. N. 1924. Insectae portoricensis. Jour. Agric. Univ. P. Rico 7: 1-312.

. 1951. The insects of Puerto Rico. Jour. Agric. Univ. P. Rico 32: 417-748.

Recebido em 21.II.2001; aceito em 06.V.2002. 